Rok Stergar $^{*}$

\title{
Hrana na bojiščih 1. svetovne vojne: izkušnje slovenskih vojakov
}

\begin{abstract}
IZVLE $\check{C E K}$
Prehrana vojakov na bojišcu je bila vedno izredno pomembna, hkrati pa je bila velik izziv za logistiko. Nezadostna preskrba namreč ni okrnila samo fizičnih sposobnosti vojakov, ampak je načenjala tudi moralo. Oskrba avstro-ogrskih vojakov v 1. svetovni vojni ni zmogla dohajati potreb in vojaki so bili zato pogosto lačni, posebno še vadnjih treh letih vojne.
\end{abstract}

Ključne besede: Avstro-Ogrska, prva svetovna vojna, vojaška izkušnja, prehranjevanje

ABSTRACT
FOOD ON WORLD WAR I BATTLEFIELDS:
EXPERIENCES OF SLOVENE SOLDIERS

The sustenance of soldiers on the battlefield had always been very important and a great challenge for the supply and support branch of the military, at the same time. Inadequate food not only left soldiers physically weak but also dispirited. The supply of food for Austro-Hungarian soldiers in World War I failed to keep up with the demand, so they were often hungry, especially during the last three years of the war. An analysis of diaries, memoires, and letters of Slovene soldiers enables an insight in their experiences and also identifies different factors that affected them.

Keywords: Austria-Hungary, World War I, experiences of soldiers, food

\section{Raziskovanje vojaških izkušenj}

V zadnjih desetletjih se je raziskovanje 1. svetovne vojne v Sloveniji precej okrepilo. ${ }^{1} \mathrm{Kljub}$ temu pa v našem poznavanju tega obdobja ostajajo pomembne bele lise

* dr., izredni profesor, Filozofska fakulteta, Univerza v Ljubljani, Aškerčeva 2, SI-1000 Ljubljana, rok.stergar@ff.uni-lj.si

Za koristne sugestije se želim zahvaliti Petri Svoljšak in anonimnima recenzentoma. Prav tako se za pripombe zahvaljujem vsem diskutantom, ki so sodelovali v razpravi, ko sem na različnih mestih predstavljal svoje prve ugotovitve na temo prehranjevanja slovenskih vojakov v 1. svetovni vojni.

1 Za stanje raziskav gl. Petra Svoljšak, "Prva svetovna vojna in Slovenci: Oris slovenskega zgodovinopisja, publicistike in spominske literature o prvi svetovni vojni, « Zgodovinski časopis 47 (1993): 
in mednje gotovo sodi vojaška izkušnja, ki zajema tako objektivne okoliščine kot tudi njihovo subjektivno doživljanje. Izšli so sicer številni vojaški dnevniki, spomini in nekatere korespondence, vendar to gradivo še ni bilo sistematično historiografsko obdelano. Vojaškim izkušnjam so zgodovinarji namenili nekaj pozornosti, vendar praviloma niso bile v fokusu zanimanja, ali pa so bile tematizirane v krajših tekstih, ki ne omogočajo zelo izčrpne obravnave. Kljub temu so zanimivi in prinašajo dragocene podatke in interpretacije. Vsekakor to velja za vrsto tekstov Marte Verginella, v katerih je analizirala avtobiografska pisanja slovensko govorečih vojakov in civilistov iz časa prve svetovne vojne. ${ }^{2}$ Prav tako je kljub majhnemu obsegu zelo koristen novejši tekst Marka Štepca, trenutno verjetno najboljšega poznavalca tematike. ${ }^{3}$ Bistveno bolj ambiciozen poskus pa je Lutharjeva monografija $O$ žalosti niti besede, vendar je žal predvsem reprodukcija britanskih mitov iz 60. let 20. stoletja, medtem ko napovedane rekonstrukcije emocionalne zgodovine v njej ni prav veliko. ${ }^{4}$

Nekoliko bolj sistematično so raziskani posamezni aspekti vojaškega življenja. Še najbolje poznamo odnos slovenskih vojakov do dvojne monarhije, države, ki jih je poslala na fronte. ${ }^{5} \mathrm{~V}$ raziskavah Pavline Bobič je prikazana vloga religije. ${ }^{6}$ Manj pa

263-87, 547-67. Idem, "Prva svetovna vojna in Slovenci 1994-2014, "Prispevki za novejšo zgodovino 55, št. 2 (2015). Gregor Joseph Kranjc, »The Neglected War: The Memory of World War I in Slovenia," The Journal of Slavic Military Studies 22 (2009): 208-35.

2 Marta Verginella, "Velika vojna v avtobiografskih zapiskih slovenskih vojakov," v: Velika vojna in Slovenci: 1914-1918, ur. Peter Vodopivec in Katja Kleindienst (Ljubljana: Slovenska matica, 2005), 175-84. izpiši Marta Verginella, "Soška fronta v slovenskem tisku in zapiskih slovenskih vojakov,"v: Soški protokol, ur. Andreas Moritsch in Gudmund Tributsch (Celovec, Ljubljana, Dunaj: Mohorjeva založba, 1994), 51-56. Marta Verginella, "La guerra è un’arte egoistica e crudele: Esperienze di guerra negli scritti di soldati austro-ungarici di nazionalità slovena," v: 1914-1918: Scampare la guerra: Renitenza, autolesionismo, comportamenti individuali e collettivi di fuga e la giustizia militare nella Grande Guerra, ur. Lucio Fabi (Ronchi dei Legionari: Centro culturale pubblico polivalente, 1994), 99-107. O slovenski avtobiografski literaturi iz časa 1. svetovne vojne gl. tudi: Petra Svoljšak, »Pisanje kot zdravilo ali oznanilo bodočim rodovom: Po slovenskih spominskih poteh vélike vojne, «Acta Histriae 19, št. 3 (2011): 523-40. Irena Novak-Popov, »'Pozabljena' slovenska pričevanja iz vélike vojne, "Jezik in slovstvo 50, št. 1 (2005): 9-24.

3 Marko Štepec, "Izkušnja vojne v dnevnikih in spominih slovenskih vojakov, "v: Sledi prve svetovne vojne v mojem kraju, ur. Ljudmila Bezlaj Krevel (Ljubljana: Zveza prijateljev mladine Slovenije, Komisija za delo zgodovinskih krožkov, 2014), 14-23.

4 Oto Luthar, "O žalosti niti besede«: Uvod v kulturno zgodovino vélike vojne (Ljubljana: Založba ZRC, 2000). Cf. Brian Bond, The Unquiet Western Front: Britain's Role in Literature and History (Cambridge, New York: Cambridge University Press, 2002).

5 Walter Lukan, "Die politische Meinung der slowenischen Bevölkerung 1917/18 im Spiegel der Zensurberichte des Gemeinsamen Zentralnachweisbureaus für Kriegsgefangene in Wien: (mit besonderer Berücksichtigung des Verfassers der Berichte - Milan Hodža)," v: Nationalismus, Gesellschaft und Kultur in Mitteleuropa im 19. und 20. Jahrhundert: Festschrift für Jiři Koralka zum 75. Geburtstag = Nacionalismus, společnost a kultura ve struedni Evropè 19. a 20. stoleti: Pocta Jiřimu Koralkovi k 75. narozeninám, ur. Jiř̌ Pokorný, Luboš Velek in Alice Velková (Praha: Karolinum, 2007), 217-83. Petra Svoljšak, "Slovenci v primežu avstrijske cenzure, « v: Velika vojna in Slovenci, 109-127. Miha Sluga, "Slovenski vojaki v prvi svetovni vojni, « Časopis za zgodovino in narodopisje 80, št. 1 (2009): 31-62; 80, št. 2 (2009): 82-112; 80, št. 3 (2009): 79-109. Bogdan Šteh, »Mamin paket zavit v 'veleizdajalsko vsebino': slovenski vojak in politika med prvo svetovno vojno, "Zgodovina za vse 15, št. 1 (2008): 139-50.

6 Pavlina Bobič, Vojna in vera: Katoliška Cerkev na Slovenskem, 1914-1918, prev. Niki Neubauer 
vemo o tem, kako so vojaki živeli na frontah in doživljali vojaške dimenzije velikega spopada. Čeprav je virov ogromno, zgodovinopisje še ni obsežneje odgovorilo na vprašanja o tem, kako so vojaki doživljali mraz in lakoto, spopade in trenutke relativnega miru, ubijanje in umiranje ... Prav tako zgodovinarji še niso celostno analizirali izkušnje množice vojnih ujetnikov; o tem je bila v zadnjih letih v mednarodnem prostoru objavljena vrsta izredno zanimivih študij. ${ }^{7}$ Celovita rekonstrukcija vojaške izkušnje, ali - bolje - vojaških izkušenj, torej ostaja deziderat.

Ob tem je treba pripomniti, da podobna ugotovitev velja za celotni prostor nekdanje Avstro-Ogrske. Spremembe, ki so z objavami študij Paula Fussella (The Great War and Modern Memory, 1975), Johna Keegana (The Face of Battle, 1976) in še nekaterih zajele anglosaško zgodovinopisje o 1 . svetovni vojni v 70. letih 20. stoletja, sočasno ali nekoliko pozneje pa tudi nekatere druge historiografije, so precej obšle Avstrijo in druge nasledstvene države. ${ }^{8}$ Zato je literature o izkušnjah avstro-ogrskih vojakov malo, medtem ko je življenje vojakov na zahodnem bojišču že dobro raziskano. V novejši kratki analizi ameriški zgodovinar Jason C. Engle, ki sicer upošteva le literaturo $\mathrm{v}$ nemščini in angleščini, poleg spominske literature izpostavi samo študijo Isabelle Brandauer o življenju vojakov na dolomitski fronti. ${ }^{9} \mathrm{~K}$ temu lahko dodamo nekaj kasneje publicirane literature, zlasti razpravo Christe Hämmerle o avstro-ogrskih vojakih na jugozahodni fronti. ${ }^{10} \mathrm{Z}$ dodatkom literature v drugih jezi-

(Celje: Celjska Mohorjeva družba, 2014). Pavlina Bobič, »V dolini smrtnih senc: vera kot zatočišče slovenskega vojaka, "v: Velika vojna in Slovenci, 128-40.

$7 \mathrm{Za}$ avstro-ogrske vojne ujetnike gl. predvsem: Alon [zdaj Iris] Rachamimov, POWs and the Great War: Captivity on the Eastern Front, The Legacy of the Great War Series (Oxford, New York: Bloomsbury Academic, 2002). Alon [zdaj Iris] Rachamimov, "The Disruptive Comforts of Drag: (Trans)Gender Performances among Prisoners of War in Russia, 1914-1920, American Historical Review 111 (April 2006): 362-82. Alon [zdaj Iris] Rachamimov, "Normalität als Travestie: Das Theaterleben k.u.k. Kriegsgefangenenoffiziere in Rußland, 1914-1920, « v: Glanz-Gewalt-Gehorsam. Militär und Gesellschaft in der Habsburgermonarchie (1800 bis 1918), ur. Laurence Cole, Martin Scheutz in Christa Hämmerle-Ehrmann (Essen: Klartext, 2010), 101-26. Hannes Leidinger in Verena Moritz, Gefangenschaft, Revolution, Heimkehr: die Bedeutung der Kriegsgefangenenproblematik für die Geschichte des Kommunismus in Mittel- und Osteuropa 1917-1920 (Wien, Köln, Weimar: Böhlau, 2003). Reinhard Nachtigal, Russland und seine österreichisch-ungarischen Kriegsgefangenen (1914-1918) (Remshalden: Greiner, 2003). Georg Wurzer, Die Kriegsgefangenen der Mittelmächte in Russland im Ersten Weltkrieg (Göttingen: Isd, 2005). Za slovenske vojne ujetnike kratko: Petra Svoljšak, »Slovenski vojni ujetniki v prvi svetovni vojni,« v: Sledi prve svetovne vojne v mojem kraju, 24-33.

8 Odličen pregled mednarodne historiografije glej v: Walter Lukan, „Zgodovinopisje o prvi svetovni vojni, "v: Velika vojna in Slovenci, 16-34.

9 Jason C. Engle, "'This Monstrous Front Will Devour Us All?' The Austro-Hungarian Soldier Experience, 1914-15,"v: 1914: Austria-Hungary, the Origins, and the First Year of World War I, ur. Günter Bischof, Ferdinand Karlhofer in Samuel R. Williamson, Jr., Contemporary Austrian Studies, 23 (New Orleans, Innsbruck: Uno Press, Innnsbruck University Press, 2014), 145-64. Isabelle Brandauer, Menschenmaterial Soldat: Alltagsleben an der Dolomitenfront im Ersten Weltkrieg 1915-1917 (Innsbruck: Golf, 2007).

10 Christa Hämmerle, "Opferhelden? Zur Geschichte der k. u. k. Soldaten an der Südwestfront, « v: Krieg in den Alpen: Österreich-Ungarn und Italien im Ersten Weltkrieg 1914-1918, ur. Nicola Labanca in Oswald Überegger (Wien, Köln, Weimar: Böhlau, 2015), 155-80. 
kih se nabor še razširi - v hrvaščini je v letu 2013 recimo izšla obsežna študija Filipa Hameršaka -, vendar ostaja skromen. ${ }^{11}$

Moja razprava tega ne bo spremenila, saj ima omejene ambicije. Lotevam se zgolj enega - vendar pomembnega - segmenta: hrane. Pri tem želim predvsem detektirati raziskovalna vprašanja in orisati problematiko ter jo predstaviti z nekaj primeri, ne da bi hkrati že ponudil definitivne odgovore. Nekoliko celoviteje bom predstavil le problematiko virov. Kompletnejša raziskava, ki bo zajela tudi mnogo več virov, pa ostaja med načrti za prihodnost.

Tematika vojaškega prehranjevanja $\mathrm{v}$ 1. svetovni vojni sicer $\mathrm{v}$ historiografiji niti približno ni izčrpana, bistveno več je objav na temo prehranjevanja civilnega prebivalstva. Raziskovalci vojaške izkušnje se hrane pogosto dotaknejo, vendar je redko v središču zanimanja. Z osredotočenostjo na prehranjevanje vojakov izstopata monografija Rachel Duffet o britanski vojski in zbornik o prehranjevanju v evropskih vojnah 20. stoletja, ki so ga uredili Duffet, Ina Zweiniger-Bargielowska in Alain Drouard. ${ }^{12} \mathrm{~V}$ njem je objavljena tudi razprava slovenske etnologinje Maje Godine Golija, ki je osredotočena na prehrano civilnega prebivalstva, vendar tako kot njena slovenska razprava iz leta 2012 vključuje tudi izkušnje vojakov. ${ }^{13}$ Prehranjevanje vojakov je tudi tema poljudno zasnovane dvojezične kuharice, ki jo je leta 2006 uredila Slavica Plahuta. Poleg številnih receptov, ki nimajo resne analitične vrednosti, vključuje tudi kratko spremno besedilo z nekaj uporabnimi informacijami. ${ }^{14}$

Skromno zanimanje za prehranjevanje vojakov v vojni je pravzaprav presenetljivo, saj je - kot sta opozorila ameriška antropologa Sydney Mintz in Christine DuBois - prehranjevanje druga najpomembnejša človekova dejavnost, takoj za dihanjem, in ima zato veliko vlogo v mnogih aspektih človeškega življenja. Tudi zato ima raziskovanje hrane in prehranjevanja $\mathrm{v}$ etnologiji in antropologiji dolgo zgodovino. ${ }^{15}$ Hkrati je potencialnim raziskovalcem na voljo množica virov, posledica množičnega vpoklica razmeroma pismene moške populacije. V slovenskem primeru imamo tako na voljo uradne dokumente, časopisna poročila, številne dnevnike, spomine, korespondenco in tudi nekaj literariziranih pričevanj.

11 Filip Hameršak, Tamna strana Marsa: Hrvatska autobiografija i Prvi svetski rat (Zagreb: Naklada Ljevak, 2013).

12 Rachel Duffet, The Stomach for Fighting: Food and the Soldiers of the Great War, Cultural History of Modern War (Manchester, New York: Manchester University Press, 2012). Rachel Duffet, Ina Zweiniger-Bargielowska in Alain Drouard, ur., Food and War in Twentieth Century Europe (Farnham: Ashgate, 2011).

13 Maja Godina Golija, »Hunger and Misery: The Influence of the First World War on the Diet of Slovenian Civilians, "v: Food and War, ur. Duffet, Zweiniger-Bargielowska in Drouard, 85-97. Maja Godina Golja, »Recepti in napotki za krizne čase: Primer slovenskega ozemlja med prvo svetovno vojno, «tnolog 22 (2012): 65-80.

14 Slavica Plahuta, ur., Kuharska knjiga - Libro di ricette (Nova Gorica: Mestna občina Nova Gorica, 2006).

15 Sidney W. Mintz in Christine M. Du Bois, "The Anthropology of Food and Eating, « Annual Review of Anthropology 31 (2002): 99-119. 


\section{Viri in problemi interpretacije}

Za rekonstrukcijo izkušenj so seveda ključni avtobiografski viri, ki nam s svojo izrazito subjektivnostjo omogočajo uvid v vojaško doživljanje vseh aspektov prehranjevanja. Vendar se je ob analizi tovrstnih dokumentov potrebno zavedati nekaterih omejitev. Najprej moramo upoštevati njihovo omejeno reprezentativnost, saj vsi socialni sloji niso sorazmerno zastopani. Čeprav tudi za slovensko govoreče vojake drži ugotovitev Paula Fussella, da so bili vojaki velike vojne v primerjavi s svojimi predhodniki izredno pismeni, je hkrati res, da so v vseh vojskah večino produkcije ustvarili pripadniki srednjega in višjih slojev družbe. Ne samo da so bili bolj pismeni - med nižjimi socialnimi sloji je marsikje bilo še precej analfabetizma - in navajeni pisanja, ampak so tako v vojni kot po njej praviloma imeli več časa, več pa je bilo tudi zanimanja za njihovo produkcijo. Zato med viri prevladujejo avtobiografska pričevanja častnikov in podčastnikov, navadni vojaki so bolje zastopani le med korespondenco. ${ }^{16}$ Izkušnje nižjih socialnih slojev je zaradi tega precej težje rekonstruirati, posebno ker je bila priložnost za sistematično zbiranje ustnih pričevanj zamujena.

Drugi moment, ki ga moramo upoštevati, je vprašljiva verodostojnost virov, in sicer ne samo na nivoju faktov, ampak tudi, ko nas zanima subjektivni vidik zapisanega. Na prvi pogled se zdi, da tega ni treba posebej poudarjati, saj preverjanje zanesljivosti informacij sodi med osnove kritike virov. Dejansko je pri raziskovalcih opazno zavedanje o vplivu cenzure in samocenzure na avtobiografske dokumente, zato morda ni treba izrecno opozoriti, da sta močno vplivali tudi na pisanje o hrani. ${ }^{17}$ Prav tako je dovolj razširjeno vedenje o specifikah spominskih tekstov, napisanih za ožjo ali širšo publiko. Ne samo da avtorji, ki se vojne spominjajo leta ali desetletja po njej, pozabljajo, ampak na njihovo pisanje vplivajo tudi literarne konvencije in prepričanja okolja, v katerem so pisali. Raziskave vojne memorialistike tako pokažejo odvisnost od časa nastanka in nagovorjene publike. ${ }^{18}$ Kot je $\mathrm{z}$ analizo serije spominov na iste dogodke, ki jih je v različnih obdobjih napisal isti avtor, izvrstno pokazal Michael Roper, pa na naracijo vpliva tudi posameznikovo predelovanje vojne izkušnje. ${ }^{19}$

16 Duffet, Stomach, 12-15. Jessica Meyer, Men of War: Masculinity and the First World War in Britain, Genders and Sexualities in History (New York: Palgrave Macmillan, 2009), 48. Verginella, Velika vojna, 179-81. Federico Mazzini, »Kriegserfahrungen: Italienische Soldaten an der italienisch-österreichischen Front, « v: Krieg in den Alpen, ur. Labanca in Überegger, 130. Cf. Paul Fussell, Velika vojna in moderni spomin, prev. Kostja Žižek in Katja Jenčič (Ljubljana: Studia Humanitatis, 2013).

17 Duffet, Stomach, 15-17.

18 Ibid., 180. Gl. tudi: Graham Dawson, Soldier Heroes: British Adventure, Empire and the Imagining of Masculinities (London, New York: Psychology Press, 1994).

19 Michael Roper, "Re-Remebering the Soldier Hero: The Psychic and Social Construction of Memory in Personal Narratives of the Great War, « History Workshop Journal 50 (2000): 181-204. V slovenski memorialistiki so morda najbolj zanimiv, na trenutke celo komičen, primer spreminjanja »Spomini« Janeza Trdine. Rokopis je namreč avtor občasno popravljal in komentiral. Svoje prvotne trditve je med drugim večkrat označil za klevete. - Janez Trdina, Zbrano delo, zv. 1: Spomini, ur. Janez Logar, Zbrana dela slovenskih pesnikov in pisateljev (Ljubljana: Državna založba Slovenije, 1946), 160, 167-68. 
Toda ob vsem povedanem je opozorilo vseeno na mestu, saj je precej manj razširjeno zavedanje, da niti teksti, ki so nastajali sproti in so bili napisani za maloštevilno publiko, torej pisma in dnevniki, niso nastajali povsem brez takšnih vplivov. Pisma in dnevniki niso "neretorična pričevanja« in težko si je predstavljati, da bi bila povsem "svetovnonazorsko nekontaminirana«. ${ }^{20}$ Tudi pisma in dnevniki - če niso povsem lapidarni - so pripovedi, ki naslavljajo publiko in jih zato v večji ali manjši meri sooblikujejo družbene konvencije in ne samo samocenzura ali luknjičav spomin. Tudi $\mathrm{v}$ pismih in dnevnikih pisci uporabljajo retorična orodja in literarizirajo svojo vojno izkušnjo. $^{21}$

Zaradi vsega tega se zgodovinar pri analizi virov pogosto znajde pred vprašanjem, ali je mogoče avtorju dokumenta verjeti, oziroma, ali se je preko analize tekstov mogoče dokopati do kolikor toliko zanesljive rekonstrukcije pretekle realnosti. $\mathrm{Na}$ primer: so bili zapisi nižjih častnikov, da je moštvo dobro prehranjeno, da ničesar ne manjka, ilustracija dejanskega stanja, ali je pisec na ta način želel povedati, da je dobro opravil svojo nalogo, in tako potrditi samopodobo uspešnega, dobrega skrbnika? Podobno velja za vojaška pisma: so bila zatrjevanja domačim, da je vse dobro in jim nič ne manjka, rezultat samocenzure ali igranja vloge brezskrbnega in junaškega vojaka, ki se nikoli ne pritožuje? So vojaki prazen želodec zamolčali, da domačih ne bi preveč skrbelo, ali pa so bili tisti trenutek res siti? ${ }^{22}$

Prepričan pa sem, da kljub navedenim pomislekom ni potrebno sprejeti epistemološkega pesimizma postmodernistov in se povsem odpovedati možnosti razmeroma verne rekonstrukcije vojaške izkušnje. Namesto tega se lahko strinjamo z britanskim zgodovinarjem Richardom J. Evansom in rečemo: „V resnici se je zgodilo in $\mathrm{v}$ resnici lahko, če smo zelo natančni in samokritični, pridemo do branljivih, a vedno nedokončnih sklepov o tem, kaj je vse skupaj pomenilo. «23 S tem optimističnim sklepom se lotimo rekonstrukcije izkušenj slovenskih vojakov v avstro-ogrski vojski $s$ hrano in prehranjevanjem.

20 Verginella, »Soška fronta, « 54. Luthar, $O$ žalosti, 15. Ker Marta Verginella sicer v svojih tekstih izpričuje dobro poznavanje problematike avtobiografskih virov, lahko citirano formulacijo pripišemo neposrečeni izbiri besed. Poleg že navedenih del gl. še: Marta Verginella, "Zgodovinopisna raba avtobiografskih virov in značilnosti ženskega avtobiografskega pisanja," v: Avtobiografski diskurz: teorija in praksa avtobiografije v literarni vedi, humanistiki in družboslovju, Studia litteraria, ur. Alenka Koron in Andrej Leben (Ljubljana: Založba ZRC, 2011), 95-108.

21 Sidonie Smith in Julia Watson, Reading Autobiography: A Guide for Interpreting Life Narratives, 2. izd. (Minneapolis: University of Minnesota Press, 2010), 13. Joanna Bourke, An Intimate Histoy of Killing: Face-to-Face Killing in the Twentieth-Century Warfare (1999; London: Basic Books, 2000), 33-37. Hameršak, Tamna strana, 110-12.

22 Duffet, Stomach, 9, 93-94. Vanda Wilcox, »Tra testo e corpo: l'esperienza fisica della Prima guerra mondiale negli scritti dei soldati, Memoria e Ricerca: Rivista di Storia Contemporanea, št. 38 (2011): 36-37.

23 Richard J. Evans, In Defence of History, 2. izd. (London: Granta, 2000), 253. 


\section{Organizacija prehranske oskrbe armad v začetku 20. stoletja}

Hrana je osnovna človekova potreba. V medijih sicer včasih beremo neverjetne zgodbe o ljudeh, ki naj bi živeli od sončne svetlobe, toda to je le odraz človeške lahkovernosti in novinarske neprofesionalnosti. Brez hrane pač ne moremo dolgo živeti, saj z njo nadomeščamo energijo, ki jo telo porablja za delovanje. Sodobni ameriški vojaški standardi dnevno porabo energije definirajo s pomočjo REE, kar je poraba energije za zagotavljanje osnovnih življenjskih funkcij (angl. Resting Energy Expenditure), torej minimum za pokrivanje dnevnih potreb. Približen izračun za 80-kilogramskega 21-letnika je $1800 \mathrm{kcal}$, zmerna aktivnost porabo poveča za faktor 1.7, težka (recimo hoja v hrib z dodatno obremenitvijo) za 2.1 in izredna aktivnost (težki tovori, kolesarjenje v hrib ...) za 2.4. ${ }^{24} \mathrm{Z}$ nekaj poenostavljanja lahko rečemo, da je dnevna energijska potreba mlajšega odraslega moškega ob zmerni aktivnosti med 2.400 in $3.000 \mathrm{kcal}$, medtem ko jo lahko močna aktivnost dvigne preko 5.000 kcal. Na porabo vplivajo tudi okoljski dejavniki (mraz, vročina); v arktičnem mrazu lahko poraba ob zmerni aktivnosti naraste do $5.000 \mathrm{kcal}$ na dan.

Seveda lahko nekaj časa preživimo z manjšim vnosom energije, vendar se razmeroma hude posledice pokažejo presenetljivo hitro. Proti koncu 2. svetovne vojne so ameriški zdravniki s skupino prostovoljcev izvedli preskus, znan kot Minnesota starvation experiment, da bi razvili metode za pomoč sestradanim žrtvam vojne $\mathrm{v}$ Evropi. Prostovoljcem so dnevni vnos omejili na $1.560 \mathrm{kcal}$, kar še ne velja za stradanje. Kljub temu so se v nekaj mesecih pojavile hude psihične in fiziološke posledice. Prostovoljci niso samo izgubili četrtine svoje teže, ampak je večina trpela za depresijo ali drugimi motnjami, prišlo je tudi do samopoškodbe. ${ }^{25}$

Vojske so se pred 1. svetovno vojno povsem zavedale pomena primernega energijskega vnosa za vojaško učinkovitost. Od začetka 20. stoletja je že bilo na voljo merjenje kalorične vrednosti hrane in armade so prehrano normirale v skladu s tedaj aktualnimi dognanji. Britanska norma za vojake na fronti je bila v začetku vojne postavljena na precej visokih $4.200 \mathrm{kcal}$, nekoliko nižja je bila italijanska, nemška in francoska pa sta bili s 3.200 oziroma $3.400 \mathrm{kcal}$ že precej manjši. ${ }^{26}$ Nekaj pozornosti so sestavljavci vojaških jedilnikov posvečali tudi sestavi, pri čemer niso upoštevali samo priljubljenosti nekaterih vrst hrane in verskih predpisov, ampak so se v manjši meri že začela uveljavljati tudi spoznanja o pomembnosti mikrohranil, predvsem

24 Human Performance Resource Center, ur., Warfighter Nutrition Guide, pogl. 2, 5, pridobljeno 3. 9. 2015, http://hprc-online.org/nutrition/warfighter-nutrition-guide-chapter-2-1/WFNutritionGuide2.pdf.

25 Todd Tucker, The Great Starvation Experiment: The Heroic Men Who Starved so That Millions Could Live (New York: Simon and Schuster, 2006).

26 Podatki v literaturi se sicer ne ujemajo povsem, gl.: Duffet, Stomach, 35, 77-78. Maria Concetta Dentoni, "Food and Nutrition (Italy), " v: 1914-1918-online. International Encyclopedia of the First World War, pridobljeno 3. 9. 2015, http://encyclopedia.1914-1918-online.net/article/food_and_nutrition_italy. Wilcox, "Tra testo e corpo, «34. Peter Lummel, "Food Provisioning in the German Army of the First World War,« v: Food and War, ur. Duffet, Zweiniger-Bargielowska in Drouard, 15. 
vitaminov. $\mathrm{V}$ vojaških predpisih so se uveljavila prej kot v civilni praksi, vendar je bil glavni poudarek kljub vsemu na energijski vrednosti hrane. ${ }^{27}$

Pomembni pa nista bili samo količina in sestava hrane, temveč predvsem to, da je prišla do vojakov. Seveda so se poveljniki vedno zavedali, da je - kot je to ubesedil vojvoda Wellingtonski - za dosego ciljev potrebno jesti. Vendar pa je bila organizacija oskrbe s hrano pogosto zelo neadekvatna. Šele od srede 19. stoletja je v evropskih vojskah prišlo do ključnih premikov. Medtem ko so bili britanski in francoski vojaki še $\mathrm{v}$ času krimske vojne $\mathrm{v}$ marsičem prepuščeni lastni iniciativi oziroma pomoči ženskih spremljevalk, je bila do 1 . svetovne vojne oskrba v celoti integrirana v vojaške strukture in profesionalizirana. $\mathrm{V}$ istem obdobju je velike izboljšave prinesel tudi tehnološki razvoj. Uveljavitev železniškega transporta je omogočila oskrbo armad na daljše razdalje in tako vojske - vsaj v teoriji - niso bile več odvisne od lokalne oskrbe in vodnega transporta. Železniška mreža pa se je v zadnji četrtini 19. in v začetku 20. stoletja izredno razvila, prav tako so se nekajkrat povečale prevozne kapacitete. Do velikih sprememb je prišlo tudi pri konzerviranju hrane. Že pred sredo 19. stoletja so se pojavile pločevinke, prav tako kondenzirano mleko in mleko v prahu ter nekateri drugi industrijsko predelani in konzervirani prehranski proizvodi, ki so bistveno olajšali oskrbo, saj so se zaloge manj kvarile. ${ }^{28}$

Vse to je v začetku 20. stoletja generalštabom omogočilo, da so bodočo vojno pričakovali s precejšnjim zaupanjem v dobro delovanje sistema prehranske oskrbe vojakov. Tudi avstro-ogrske oborožene sile so sistem skrbno načrtovale, njegovo delovanje pa večkrat preskusile na manevrih. Skrbele so tudi za posodabljanje opreme in v tem okviru nekaj let pred vojno, leta 1909, kupile več tisoč kuhinj na vozovih in $\mathrm{v}$ zabojih, da bi vojake razbremenile časovno zamudnega večernega pripravljanja hrane. Takšne kuhinje je dobila vsaka četa oziroma eskadron. Poskrbljeno je bilo tudi za čas neoptimalnega delovanja sistema, saj so enote imele zaloge, ki naj bi zadostovale za slab teden bojevanja. ${ }^{29}$ Zadnjo, tako imenovano železno rezervo, so vojaki nosili s seboj. Znameniti dunajski skladatelj in violinist Friedrich Kreisler, ki je leta 1914 kratko služil v graškem črnovojniškem polku, se spominja, da je v prepolnem nahrbtniku nosil tudi konzervirano meso, riž, kavni ekstrakt, prepečenec in sol ter sladkor. ${ }^{30}$

A tehnološki razvoj, izpopolnitev železniškega omrežja, skrbno načrtovanje in vse drugo ni moglo rešiti problema oskrbe na taktičnem nivoju, ki se je močno zaostril z

27 Duffet, Stomach, 35, 58. Slavica Plahuta, »Prehrana civilistov in vojakov na Goriškem v času bojev na Soči: 1915-1917, "v: Kuharska knjiga, ur. Plahuta, 11.

28 John Keegan, A History of Warfare (1993; London: Pimlico, 1994), pogl. "Logistics and Supply, 301-15. Martin van Creveld, Supplying War: Logistics from Wallenstein to Patton, 2. izd. (Cambridge, New York: Cambridge University Press, 2004), 82-108, 111-12.

29 Walter Wagner, „Die k.(u.)k. Armee - Gliederung und Aufgabenstellung, « v: Die Habsburgermonarchie 1848-1918, ur. Adam Wandruszka in Peter Urbanitsch, zv. 5, Die bewaffnete Macht (Wien: Österreichische Akademie der Wissenschaften, 1987), 560-67.

30 Fritz Kreisler, Four Weeks in the Trenches: The War Story of a Violinist (Boston, New York: Houghton Mifflin, 1915), 13. Gl. tudi Plahuta, »Prehrana civilistov in vojakov, "11. Wagner, »Die k.(u.) k. Armee, 567. 
eksponentnim povečanjem armad in prav takšnim povečanjem potreb po vojaškem materialu in hrani ter pijači za ljudi in živali. Medtem ko so železnice dohajale rast potreb po oskrbi na večje razdalje, taktična oskrba še ni doživela tehnološke revolucije, ampak je še vedno temeljila na delu ljudi in živali. Zato se je taktična mobilnost enot od vojn za nemško združitev do začetka 20. stoletja zmanjšala; v grobem se je celo prepolovila s 100 na 50 milj, razdalja od zadnje železniške postaje, na kateri so enote lahko računale na delovanje oskrbe. ${ }^{31}$

\section{Začetek spopada: preskus sistema $\mathrm{v}$ praksi}

Toda na začetku spopadov ti problemi še niso bili očitni, čeprav so jih specialisti za logistiko zaznali že pred začetkom vojne. Slovenski popularni časnik Tedenske slike je ob koncu septembra 1914 še optimistično zapisal, da je »[z]a prehrano vojske ... dobro poskrbljeno. Vsak vojak dobi dovolj dobre in tečne hrane.«32 Dejansko začetne izkušnje slovenskih vojakov, podčastnikov in častnikov niso bile slabe. Predvsem slednji so ob mobilizaciji poskrbeli za privatne zaloge, tako da niso bili samo siti, ampak so se obenem postopoma privadili na vojaško prehranjevanje. Janko Hacin, rezervni nadporočnik, je na poti v Bosno jedel svojo »klobaso, salamo in sir«, pa tudi "pečeno gos", ki jo je z njim delil zdravnik na poti v vojsko. ${ }^{33}$

Hacin je v Bosni doživel tudi drugo pogosto značilnost začetnega obdobja: obdarovanje $s$ hrano s strani civilistov. Kot poveljujoči častnik je od župana Tuzle za vojake dobil tobak in »čokolade, vina, konjaka, klobas itd. «34 Čeprav tudi vojaški dnevniki in spomini potrjujejo potrebo po relativizaciji vojnega navdušenja, in sicer v vseh državah, je bilo v prvih tednih navdušencev vseeno dovolj, hrane pa tudi, ter je odhode prvih enot na fronto praviloma zaznamovala obilica hrane. Polna so bila tudi vojaška skladišča, enote pa so bile še na območjih mobilizacije in koncentracije, tako da je sistem dobro deloval. V začetnem obdobju vojne so se nekateri britanski vojaki celo zredili, podobno je slabo leto kasneje veljalo za italijanske. Vendar razlog ni bila le dobra in obilna hrana v vojski, ampak tudi slaba prehranjenost velikega dela vojakov v civilnem življenju. Redni in predvsem z mesom bogati obroki so bili za revne mobilizirance ali prostovoljce pomembna pridobitev. 35

Vendar so se v avstro-ogrski vojski že od začetka mobilizacije kazale ali vsaj nakazovale težave. Kljub temu da so imele enote mobilne kuhinje, so po nepotrebnem izgubljale veliko časa z večurnimi pavzami za hrano. Še huje je bilo, da ob začetku ofenzive na balkanskem bojišču vse oskrbovalne kolone niso dosegle načrtovanih

31 Van Creveld, Supplying War, 112-13.

32 „Kako prehranijo armado, "Tedenske slike, 23. 9. 1914, 5, 9-10.

33 Janko Hacin, Vsi ti mladi fantje (Ljubljana: Slovenska matica, 2002), 25.

34 Ibid., 26. Nekaj podobnega se je morda - gotovo pa v manjši meri - dogajalo po vstopu Italije $\mathrm{v}$ vojno, maja 1915. Vendar pa Matičičev opis navdušenih domačinov, ki vojakom nosijo krompir in češnje, ne zveni prepričljivo. - Ivan Matičič, Na krvavih poljanah: Trpljenje in strahote z bojnih pohodov bivšega slovenskega planinskega polka (1922; Ljubljana: Karantanija, 2006), 20-21.

35 Duffet, Stomach, 77. Wilcox, "Tra testo e corpo» «34-36. 
položajev. ${ }^{36}$ Po prečkanju srbske meje in z oddaljevanjem od železniških postaj so se težave samo še povečevale, saj so bile enote odvisne od oskrbe po težavnem terenu z izredno slabo prometno infrastrukturo. Več dni so ostajale brez pijače in sveže hrane ter so bile odvisne od rezerve, ki so jo vojaki nosili s seboj. Prav izčrpanost, ki je bila tudi posledica pomanjkljive oskrbe $s$ hrano, je bila med ključnimi razlogi za poraz 21. domobranske divizije na Cerski planini in $s$ tem za neuspeh prve avstro-ogrske ofenzive v Srbijo. 37

Podobna je bila situacija na drugih bojiščih. Oskrbovalne kolone, tudi mobilne kuhinje, so s težavo dohajale pehoto, ali pa je sploh niso, tako da so bili vojaki prisiljeni pojesti železno rezervo oziroma so bili lačni. Že omenjeni Janko Hacin, ki je bil ob koncu leta na vzhodu, je v svoj dnevnik 14. decembra zapisal: "Medtem ko je predvčerajšnjim prišel tren za nami šele ob 12. uri ponoči, so včeraj okoli polnoči prišle za nami samo kuhinje, ostali tren pa šele danes opoldne« in dodal: »Moštvo ni včeraj jedlo ničesar. Le zjutraj je dobilo kavo in isto tudi zvečer.« Dva dni pozneje pa je napisal: „Vojaki grejejo svoje konzerve na ognjih, kajti naše kuhinje so ostale v blatu daleč za nami.«38 $\mathrm{V}$ posameznih primerih so si enote v takšnih situacijah pomagale z lokalno oskrbo - Ciril Prestor je v času novembrske ofenzive v Srbijo v dnevnik zapisal, da je »[k]okoši, prašičkov in vsega dovolj« - vendar le, če zaloge še niso bile izčrpane. ${ }^{39}$

Ko pa je na terenu vsega zmanjkalo, so bile čete, ki so bile predaleč od železnice, v velikih težavah, saj oskrba z vozovi ni zmogla dostaviti potrebnih količin hrane, posebno še, če je bil teren težko prehoden. Celo v propagandnih Tedenskih slikah so septembra 1914 priznali: "Jako težavno delo je imel provijantni tren, ki se je v močvirju pomikal dalje le z najhujšim naporom in seveda včasih tudi z zamudo. ${ }^{40}{ }^{\mathrm{S} e}$ jasneje je položaj v dnevniku opisal Hacin:

Tu v Włodzimierzu ni dobiti ničesar. Pred nami so bili tu pet tednov Rusi, za njimi Nemci in sedaj mi. V celi vasi ni kg moke, le malo, pa zelo malo krompirja. Bukvica, moj korporal, ga je kupil pri gospodinji in spekel. Od kuhinje je danes moštvo dobilo le krompir. Za jutri je kupil Koukal tri vole, ki so jih takoj pobili in odrli na zeleni trati ob najlepšem dežju.

Predvčerajšnjim je povedal nek štabni zdravnik, da je vsako oskrbovanje nemogoče. Ker je pot tako dolga, pridejo vozovi do čet že čisto prazni, "weil die Verpflegsstaffeln sich selbst verzehren«.... Konji dobijo namesto ovsa in sena samo slamo in je zato povsod ob poti vi-

36 Manfried Rauchensteiner, Der Tod des Doppeladlers: Osterreich-Ungarn und der Erste Weltkrieg (Graz, Wien, Köln: Böhlau, 1997), 119, 129. John R. Schindler, "Disaster on the Drina: The Austro-Hungarian Army in Serbia, 1914, "War in History 9 (2002): 162. Standardna študija avstro-ogrske mobilizacije je sicer: Norman Stone, "Die Mobilmachung der österreichisch-ungarischen Armee 1914," Militärgeschichtliche Mitteilungen 16 (1974): 67-95.

37 Schindler, "Disaster on the Drina, «171, 176.

38 Hacin, Vsi ti mladi fantje, 31-33.

39 Luthar, $O$ žalosti, 130-31. Prestorjev dnevnik je bil že prej integralno objavljen v: Eva Holz, »Dnevnik Cirila Prestorja iz 1. svetovne vojne, Kronika 34, št. 1/2 (1986): 72-88.

40 Tedenske slike, 23. 9. 1914, 3. 
deti žalostne ostanke poginulih. Tu sem slišal, da so vse daljše operacije izključene, dokler ne bo popravljena železnica Częstochowa-Piotrków, ker je nemogoče ljudi preživeti. ${ }^{41}$

\section{Razlogi za težave pri oskrbi}

Seveda se zastavlja vprašanje, zakaj je ob vsem načrtovanju že od začetka spopadov prihajalo do takšnih situacij. Razloge lahko iščemo v vrsti dejavnikov, med katerimi so na prvem mesto prav gotovo količine materiala, ki ga je bilo potrebno pripeljati na fronto. Za ilustracijo poglejmo nemški primer: že v prvih dveh letih vojne so enotam dostavili skoraj 1.2 milijona ton moke, milijon glav goveda, milijon prašičev, skoraj 600.000 ovc in še 275.000 ton mesa v konzervah, 62.500 ton kave in 15.000 ton kakava in čaja, 2.7 milijona hektolitrov piva. S cigaretami in cigarami so količine dosegle 8 milijonov ton. ${ }^{42}$ Toda to je bil vrh ledene gore, saj moramo prišteti še moštvo, vojni material (orožje, strelivo ...) in ogromne količine krme za vlečne živali pri artileriji in taktičnem transportu. Britanci so recimo med vojno na zahodno fronto pritovorili skoraj pet in pol milijonov ton krme, kar je bilo celo nekoliko več, kot je tehtalo pripeljano strelivo. ${ }^{43}$

Transportne zmogljivosti vseh vojskujočih se držav so zaradi ogromnih potreb delovale na skrajnem robu zmogljivosti in kljub temu včasih niso dohajale zahtev. Kot sem že omenil, so bile težave očitne predvsem na taktičnem nivoju, saj je bila strateška logistika ob delujočem železniškem omrežju dovolj dobro rešena. Drugače je bilo, ko je bilo vse potrebno transportirati z vozovi, tovorno živino ali peš. Ker je pehotna divizija dnevno potrebovala okrog 40 ton prehrambnega materiala, kar je od 50 do 100 vozov, so se hitro pojavili problemi. ${ }^{44}$ Posebno tam, kjer je bilo cestno omrežje v slabem stanju in je bilo cest malo, je pratež hitro zatrpal vse poti. Dnevniki, pisma in spomini vojakov pričajo, da se je na Balkanu in v Rusiji to pogosto dogajalo. Zdravnik Otto Hawlina, rezervni stotnik, je 22. avgusta 1914 nekje v Galiciji zapisal: "Zaradi divizijskega prateža pogosto prihaja do zastojev«, 8. septembra pa dodal: "Dolgo čakamo na cesti, da je pratež mimo. « Nato je 13. septembra zapisal: "Zaradi zastojev prateža se pomikamo zelo počasi in pogosto zelo dolgo čakamo na poti«, 17. septembra: „Cele ure stojimo na cesti, ki jo je zatrpal pratež«, in 19. septembra: "Vendar spet neskončni zastoji s pratežem. « 45

$\mathrm{V}$ takšnih situacijah se je oskrba iz skladišč močno upočasnila ali povsem ustavila in kratko so potegnili vojaki, saj je bil za vojsko na prvem mestu vojni material, nato krma in šele nazadnje prehrana za vojake, čeprav je bilo poveljnikom jasno, kako pomembna je. A hkrati so vedeli tudi, da je lačen vojak z delujočo puško in ustrezno

41 Hacin, Vsi ti mladi fantje, 35.

42 Lummel, „Food Provisioning in the German Army, 18.

43 Duffet, Stomach, 108.

44 Brandauer, Menschenmaterial Soldat, 205.

45 Otto Hawlina, "Galicija 1914: Vojni zapiski od junija 1914 do januarja 1915, "prev. Peter Hawlina, neobjavljen rokopis. Petru Hawlini se zahvaljujem, ker mi je odstopil prevod dnevnika, ki je v privatni lasti. 
zalogo streliva vojaško bistveno učinkovitejši kot sit vojak s pokvarjeno puško ali brez streliva.

Nezadostnost taktične logistike, ki je v največjem delu še vedno temeljila na delu ljudi in živali, je bila očitna predvsem v trenutkih premikov. Ko so bile vojske stacionarne, se je sistem stabiliziral in težave niso bile nerešljive. Oskrba na zahodni fronti je bila zato praviloma stabilna, medtem ko je bil položaj na balkanskem bojišču in na vzhodu, kjer se je boril velik del avstro-ogrskih armad, drugačen. Bojevanje na obeh frontah je bilo bolj mobilno, zaznamovali so ga veliki in razmeroma hitri premiki fronte, zato je bilo oskrbo mnogo težje zagotoviti. Avtobiografski viri slovenskih vojakov to potrjujejo, saj so pogosti zapisi, ki omenjajo težave ali celo zlom oskrbe ob večjih premikih. Takrat so bili vojaki neredko - kot je med umikom pred Rusi julija 1915 zapisal Ciril Prestor - »[1]ačni kot volkovi. «46 $\mathrm{Na}$ jugozahodni fronti, kjer so bile linije veliko bolj statične, je bilo takšnih situacij manj, saj je vojska do bojišča zgradila obsežno transportno infrastrukturo, ki je poleg cest zajemala tudi žičnice in predvsem bojiščne železniške proge. ${ }^{47}$ Nemalo pa je k zanesljivosti oskrbe prispevala tudi manjša razsežnost bojišča.

Zato pa je bila v bojih z Italijo, predvsem na Krasu, moteč element velika intenzivnost spopadov. Večja gostota vojaštva in oborožitve je privedla do pogostejšega in močnejšega obstreljevanja, pogosto skoncentriranega prav na oskrbovalne linije. Frontna črta je bila namreč po začetnem obdobju že tako utrjena, da je bil učinek artilerijskega ognja majhen, medtem ko so bile dostopne poti bolj izpostavljene. V času najhujših spopadov se je z vso ostrino pojavil problem zadnjih sto ali dvesto metrov, ki so ga zelo dobro poznali na zahodni fronti. Med drugim so ga poskušali reševati z nočno dostavo hrane. Franjo Malgaj opisuje oskrbo med boji na Doberdobski planoti: „Ker podnevi sploh ni smel nihče pokazati glave iz svojega bivališča, so nam hrano prinašali le ponoči. ... Vzdolž rova so nosili kotle z menažo. « $48 \mathrm{~V}$ času najbolj intenzivnih spopadov hrane včasih niti v temi ni bilo mogoče spraviti do vojakov na frontni liniji. Malgaj je zapisal: "Zgodilo se je, da so nam Lahi z granatami pobili tovorno živino, ki nam je ponoči prinašala proviant (hrano ali črno kavo).« Poljski vojak iz Galicije, ki se je tudi boril nekje na Krasu, pa se spominja: „Bila so tudi taka obdobja, da po tri dni nismo nič jedli, ker so po poti umrli ti, ki so šli po hrano, ali pa je bilo obstreljevanje tako gosto, da nisi mogel pokazati glave. « 49

$\mathrm{V}$ manjši meri, a vseeno, se je nekaj podobnega dogajalo tudi na vzhodu - Jože

46 Luthar, $O \check{z}$ alosti, 144.

47 Walther Schaumann, Die Bahnen zwischen Ortler und Isonzo 1914-1918 (Wien: Bohmann, 1991). Stane Kumar, „Vojaške železnice na Slovenskem, « Kronika 33, št. 1 (1985): 58-61. Dejan Colja, "Vojaške železnice v naših krajih,"v: Črni Vrh pod Avstro-Ogrsko (Črni Vrh nad Idrijo: samozaložba, 2014), 145-72.

48 Franjo Malgaj, Vojni spomini 1914-1919, ur. Marijan F. Kranjc in Janko Štampfl (Maribor: Pro-Andy, 2009), 101.

49 Ibid., 102. Poljski vojak je cit. pri Michał Janik, "Front Soczy w relacjach i wspomnieniach Polaków, «neobjavljen referat s simpozija W Galicji i nad Socza : Polacy $i$ Stoweńcy na frontach I wojny światowej, Krakov, 29.-30. maj 2014. Tekst bo predvidoma v letu 2015 natisnjen v zborniku s simpozija, kolegu Janiku pa se zahvaljujem za posredovani rokopis. 
Hameršak opisuje »neznosno žejo«, posledico silovitega ruskega obstreljevanja -, in tako tam kot na jugozahodni fronti so enako težavo imeli nasprotniki. Zato je včasih prišlo do neformalnih premirij, ki so omogočala vsaj za silo nemoteno prehranjevanje. ${ }^{50}$ Vendar so bila vedno krhka, pogosto so se končala zaradi preveč razvnetih vojakov ali častnikov na tej ali oni strani. Primer najdemo v dnevniku Janka Hacina, ki opisuje, kako se je v začetku leta 1915 na njegovem odseku fronte oblikoval tihi dogovor, da »mi nanje ne streljamo in ... zato tudi oni ne streljajo.«Toda položaj se je spremenil po prihodu novega polka v strelske jarke:

A enkrat proti večeru je prišla k Rusom kuhinja in tu se je naenkrat prikazalo 12 Rusov. Par ostrostrelcem žilica ni dala miru, bum, bum in 8 Rusov je padlo na tla. Od takrat se Rusi seveda revanžirajo z enakim. ${ }^{51}$

Izkušnje z zahodne fronte govorijo, da je bilo popuščanja nasprotniku s trajanjem spopadov vse manj, medtem ko se za vzhodno fronto zdi, da to ne drži. Jože Hameršak, rezervni podčastnik $\mathrm{v} 35$. pešpolku, $\mathrm{v}$ spominih navaja zanimivo epizodo iz drugega vojnega leta, iz avgusta 1915. Patrulja, ki jo je vodil, je v vasi, ki je bila med bojnima linijama, naletela na skupinico ruskih vojakov, jih poskusila zajeti, vendar se Rusi niso želeli vdati. Napeta situacija se je končala nepričakovano:

Njihov poveljnik nam pravi: Predajte se raje vi, nič hudega se vam ne bo zgodilo in lačni ne boste. Tako smo se pogajali nekaj časa in drug drugemu zagotavljali, da ne bomo šli z drugimi. Tudi oni so bili na obhodu, samo da je bilo Rusov dvanajst, nas pa pet.

Nagovarjali so nas, naj prisedemo k njim, da nas bodo pogostili. Dali so nam častno besedo, da nas bodo pustili popolnoma svobodno oditi. Sedeli so bili okrog mize, ki je bila lepo obložena s kruhom in špehom.

Ko vse to vidimo, se nam cedijo sline in želodec nas priganja, da naj prisedemo. Nazadnje še mi odložimo puške ter posedemo med Ruse. Je pač imel njihov kruh in špeh več moči kakor mi. Dali so nam kruha in špeha, mi pa njim cigarete. ${ }^{52}$

Nekateri podatki kažejo, da so se tudi na jugozahodnem bojišču podobne prakse ohranile skozi celotno vojno, in sicer predvsem v gorah, kjer so se spopadale manjše enote. Še več, Mark Thompson opozarja, da so le na tem bojišču dokumentirani primeri, ko je do neformalnih premirij prišlo sredi najhujših bojev. Nekajkrat se je zgodilo, da ena stran ni več zdržala neusmiljenega masakra in je ustavila ogenj ter nasprotnike pozvala, da tudi oni nehajo streljati. ${ }^{53}$ Vsekakor se je kaj takega zgodilo le izjemoma, medtem ko so bili manjši, skorajda individualni dogovori pogostejši.

50 Duffet, Stomach, 120-23. Mark Thompson, The White War: Life and Death on the Italian Front 1915-1919 (2008; London: Basic Books, 2009), 149-51. Za citat gl. Jože Hameršak, Skoz prvo svetovno, ur. Milan Dolgan (Ljubljana: Mladinska knjiga, 1994), 15.

51 Hacin, Vsi ti mladi fantje, 86-87.

52 Hameršak, Skoz prvo svetovno, 24.

53 Thompson, The White War, 1-3. Mazzini, „Kriegserfahrungen, 139. 
Andrej Zlobec v spominih pripoveduje, da je s svojimi italijanskimi nasprotniki redno komuniciral, ko je bil sam v opazovalnici na znameniti Col di Lana. Italijanski vojaki so ga celo vabili, da bi z njimi igral karte za hrano, česar pa si vendar ni upal storiti. ${ }^{54}$ Karel Jagodič, enoletni prostovoljec celjskega 87. pešpolka, pa je v dnevnik zapisal, kako so s tovariši na Škabrijelu pri miru pustili italijanskega vojaka, ki je z bojišča nosil ranjenca. Namesto da bi streljali, so "strme [občudovali] junaštvo«. 55

Vsekakor bi bilo problematiko vredno še sistematično raziskati. Gotovo pa je na vseh bojiščih, tudi tam, kjer se je bojevala avstro-ogrska vojska, prihajalo do načrtnega obstreljevanja kuhinj ali dostopnih poti in frontnih jarkov $\mathrm{v}$ času obrokov, da bi preprečili dostavo hrane in prehranjevanje. ${ }^{56}$ "Okrog 5 h popoldne ruska artilerija okrog naših kuhinj«, je 28. julija 1915 lapidarno zapisal rezervni nadporočnik Franc Zupančič, medtem ko je v začetku septembra 1917 Jože Selan v svoje zapiske zabeležil, da je "pri menaži ... (Italjan) metal gas granate«. ${ }^{57}$ Takšno nadlegovanje je brez dvoma imelo vojaški smisel, saj je izčrpavalo nasprotnikove vojake.

Zadnji dejavnik, ki ga velja posebej omeniti, je vreme. Na prehranjevanje je vplivalo na dva načina. $\mathrm{Na}$ eni strani so ekstremne vremenske razmere, mraz ali vročina, povečevale potrebe po vnosu hrane ali pijače. Zlasti s Krasa imamo kup pričevanj o vplivu hude poletne vročine na počutje vojakov, ki so le redko dobili dovolj pijače. Mark Thompson navaja avstro-ogrskega častnika, ki pravi, da je vroče sonce sušilo drevesno listje in travo ter vojaške čutarice, jeziki so ob pomanjkanju vode in druge pijače otekali. ${ }^{58}$ Podobno je položaj opisal Franjo Malgaj: "Vode nismo imeli niti za piti ... Vojaki so prosili za vodo, ust niso mogli več zapirati zaradi sopare. ... žejo ... smo trpeli dva dni. Če pa smo na srečo dobili vodo, potem jo je dobil vsak le toliko, da si je za nekaj minut namočil suho grlo. ${ }^{59}$ Analiza poljskih virov pokaže, da so vojaki dnevno dobivali le od pol do enega litra vode, in sicer za pitje in osebno higieno. Slednji so se zato običajno odpovedali. ${ }^{60}$ Pomanjkanje vode so doživljali tudi vojaki drugih vojsk, Britanci in drugi zavezniki morda najbolj izrazito pri Galipoliju, ni pa bilo značilno le za vroče kraje, ampak se je težava pojavljala tudi v visokogorju. ${ }^{61}$

Vreme je po drugi strani vplivalo na zanesljivost oskrbe. Predvsem bojevanje v visokogorju, v Dolomitih so se vojaki bojevali tudi nad 3.000 metri, je oskrbo s hrano

54 Andrej Zlobec, V viharju prve svetovne vojne, ur. Dušica Kunaver, V vihri petih vojn, 1 (Ljubljana: samozaložba, 2010), 137-41.

55 Karel Jagodič, "Med življenjem in smrtjo: Iz dnevnikov in pisem iz I. svetovne vojne, « ur. Janko Moder, Borec : Revija za zgodovino NOB in ohranjanje revolucionarnih tradicij 40 (1988): 702.

56 Duffet, Stomach, 121.

57 Franc Zupančič, Dnevnik: 1914-1918, ur. Jasmina Pogačnik (Ljubljana: Slovenska matica, 1998), 29. Stanislav Južnič, »Soška fronta v zapisih Jožeta Selana iz Novih sel,« Kronika 46, št. 3 (1998): 95.

58 Thompson, The White War, 108.

59 Malgaj, Vojni spomini, 102.

60 Janik, »Front Soczy«. Zelo zanimivo je tudi besedilo Andreja Zlobca, ki je tedaj še kot civilist sodeloval pri dostavljanju vode na fronto, opazoval pa je tudi izgradnjo vodovoda, ki je precej omilil probleme: Zlobec, V viharju, 41-43, 66-70.

61 Duffet, Stomach, 164-65. Hämmerle, „Opferhelden?, 174. 
postavljalo pred velike izzive. $\mathrm{V}$ ekstremnih pogojih, ko se je zaradi višine in mraza poraba energije močno povečala, je bila dostava težavna v vseh letnih časih in v vsakem vremenu, medtem ko je bila v slabem vremenu, posebno ob močnem sneženju, nemogoča. Rezervni poročnik 17. pešpolka Franc Rueh je položaj sredi decembra 1916 orisal: "Začel je padati sneg in nas popolnoma zasul, da sta cesta ... in železnica popolnoma prekinjeni. Popolnoma je ustavljen ves promet na železnici." ${ }^{62} \mathrm{~V}$ Alpah in Dolomitih pa je snežilo pogosto, občasno celo v poletnih mesecih. Takrat so bile posadke na izpostavljenih mestih več dni odrezane od oskrbe in odvisne od rezerv, ki so bile sicer prav zaradi muhastega vremena večje, a včasih niso zadostovale in so vojaki stradali. To je povečevalo možnost poškodb, predvsem ozeblin, in bolezni ter krhalo moralo. ${ }^{63}$ Ciril Prestor, ki je lačen doživel junijski sneg in mraz v trdnjavi Forte Cherle, na višini 1445 m, je svoje občutke strnil: „Fental bi se če bi človek tako rad ne živel.« ${ }^{64} \mathrm{~V}$ takšnih situacijah so poveljniki izboljševali razpoloženje in preganjali mraz ter lakoto s pomočjo vina in žganih pijač, kar pa je bil zasilen ukrep, ki predvsem v gorah ni mogel prinesti dobrih rezultatov. 65

Seveda sneg in mraz oskrbe nista oteževala ali onemogočala zgolj na jugozahodnem bojišču, gore so bile tudi na vzhodu, precejšen problem sta predstavljala tudi v nižinah. Janko Hacin je med boji na ruskem bojišču ob koncu decembra 1914 v svoj dnevnik zapisal: "Večerjo oz. kosilo smo čakali zaman. To je bilo tem bolj usodno, ker je proti jutru začelo snežiti in deževati in je bil mraz toliko bolj neznosen, ker so bili želodci prazni«, malo pozneje pa si je Ciril Prestor, ki je bil takrat tudi na vzhodu, zabeležil: "Mraz vedno hujši, pota slaba, jedli manj, skladišča daleč za nami, treba je bilo za moštvo slanine kruh [sic] in gorak čaj z rumom. 36 stopinj mraza.« 66

Le nekoliko manjša nevšečnost je bil za vojake in logistiko dež. Napolnil je jarke, močil obleko in obutev, ceste in poti pa je blato naredilo slabo prehodne ali neprehodne. Septembra 1915 je Otto Hawlina opisal posledice deževja, ki so jih poznali tudi vsi drugi:

Močno dežuje, pravi dež. Ob devetih zjutraj smo še vedno na istem mestu na cesti in tudi danes bomo težko prišli do Tarnowske, našega cilja. ... Do šestih zvečer nismo še naredili dveh kilometrov, ko so bile ceste tako razmehčane in blatne, da smo imeli zaradi prateža, ki je bil pred nami vedno znova zastoje. Kolesa so se nam včasih pogrezala do osi. ${ }^{67}$

62 Franc Rueh, Moj dnevnik: 1915-1918, ur. Igor Vilfan (Ljubljana: Slovenska matica, 1999), 83.

63 Hämmerle, »Opferhelden?«. Brandauer, Menschenmaterial Soldat, 219-20. Za italijansko vojsko, ki je imela podobne, v začetku celo večje, težave, gl.: Thompson, The White War, pogl. "Whiteness, « 193-206 in passim. Mazzini, »Kriegserfahrungen, «136-37.

64 Luthar, $O$ žalosti, 162.

65 Brandauer, Menschenmaterial Soldat, 221-22.

66 Hacin, Vsi ti mladi fantje, 50. Luthar, $O$ žalosti, 138.

67 Hawlina, "Galicija 1914, "vpis za 20. september 1914. 


\section{Poskusi reševanja logističnih težav}

Težave z logistiko niso bile nepredvidljive in vojske so se jih dejansko zavedale že pred vojno. Zato so $v$ avstrijskem primeru načrtovali, da se bodo enote $v$ kar največji meri oskrbovale lokalno. Velik delež hrane za vojake naj bi pridobili v neposredni bližini bojišča, in sicer s prostovoljno ali prisilno prodajo, lahko pa tudi z zaplembami. Toda kmalu se je pokazalo, da je bilo takšno načrtovanje povsem nerealno, saj potrebnih količin preprosto ni bilo mogoče ne kupiti ne zapleniti. ${ }^{68}$

Obremenitev transportnih zmogljivosti s prevozom hrane je armada poskušala zmanjšati na druge načine. Tudi zato so poskušali zaloge čim bolje izkoristiti. Porabili so tudi tiste dele živali, ki bi sicer končali kot klavni odpadki; iz njih so delali klobase, goveji in prašičji sečni mehurji ter osrčniki pa so bili uporabni kot vrečke za tobak in celo kot grelci za noge. ${ }^{69}$ Poleg tega so se, kjer so bili ustrezni pogoji, lotili pridelovanja hrane. Britanska vojska na zahodni fronti se je osredotočila na pridelovanje hitro pokvarljivih pridelkov, predvsem zelenjave, v zaledju Soluna pa so po izkrcanju skupaj s Francozi ustanovili celo kmetijsko šolo in organizirali nekaj vzorčnih kmetij. ${ }^{70}$ Avstro-ogrska vojska vojakov ni samo pošiljala domov na žetveni dopust, ampak se je vsaj epizodno prav tako lotila pridelave hrane na bojičču. Ciril Prestor je na primer zapisal, da so sredi aprila 1918 v Furlaniji »700 kg krompirja vsadili.«71

Vendar učinki teh prizadevanj niso bili veliki in ob vseh težavah je pravzaprav presenetljivo, da so bili vojaki, podčastniki in častniki kadarkoli siti. Toda viri dovolj jasno kažejo, da so bili tudi takšni trenutki in je torej logistika del časa vendarle solidno delovala. "Hrano imamo dobro «, "Za jesti in piti dovolj«" "Ko zberem celo kompanijo, smo se pošteno menažirali«, "Kruha je dost«, so samo nekateri komentarji, ki to potrjujejo. ${ }^{72}$ Vendar ob branju virov vendarle prevladuje vtis, da so bili vojaki večkrat lačni kot siti. Pogosto lakoto avstro-ogrskih vojakov omenja tudi literatura.

\section{Razlike v dostopu do hrane}

Nedvomno pa je bilo v tej splošni podobi veliko različnih situacij. Ali je bil vojak lačen ali sit, ni bilo odvisno samo od delovanja vojaške logistike, ampak tudi od nekaterih drugih okoliščin. Veliko je bilo seveda odvisno od posameznikovega položaja $\mathrm{v}$ armadi. Najbolj in skoraj brez izjem so bile opazne razlike med vojaki in častniki. Ne samo da so slednji načeloma in v praksi imeli boljšo oskrbo, ampak so imeli tudi svoje sluge, ki so iskali hrano in jo pripravljali. Poleg tega so običajno imeli denar, $s$

68 Brandauer, Menschenmaterial Soldat, 204-07.

69 Ibid., 222-23.

70 Duffet, Stomach, 123-25. Mark Mazower, Salonica, City of Ghosts: Christians, Muslims and Jews, 1430-1950 (2004; New York: Alfred A. Knopf, 2005), 296.

71 Luthar, $O$ žalosti, 189.

72 Rueh, Moj dnevnik, 13. Luthar, O žalosti, 143. Zupančič, Dnevnik, 46-47. Franc Reberšek, "Pisma slovenskega vojaka iz I. svetovne vojne, ur. Janez Cvirn, Borec: Revija za zgodovino NOB in ohranjanje revolucionarnih tradicij 40 (1988): 775. 
katerim so lahko nakupili tako hrano kot pijačo. Tudi če z nekaj rezerve vzamemo trditve slovenskega rusofila Aleksandra (Rudolfa) Trušnoviča, leta 1914 rezervnega častnika v avstro-ogrski armadi, da so častniki dobivali več hrane kot cela četa vojakov, ki so skoraj stradali, ni dvoma, da so bile razlike velike. ${ }^{73} \mathrm{O}$ tem pričajo tudi drugi viri, med drugim si je ljubljanski škof Anton Bonaventura Jeglič v svoj dnevnik januarja 1917 zapisal, da mu je neki vojak v pismu potožil: »'Rdeči križ' ni za nič, vse pojedo in popijo [sic] oficirji z nesramnicami« in "prav žive vsi sarži, moštvo pa strada.$^{74}$ Res pa je tudi, da v tem pogledu avstro-ogrska vojska ni bila nikakršna izjema, razlike so bile velike v vseh vojskah. Medtem ko so britanski vojaki razmišljali o "obrokih", sta častnike zanimala "hrana in vino«, ugotavlja Rachel Duffet. ${ }^{75}$

Trušnovičevi spomini dokazujejo, da so nižji častniki, ki so bili v nenehnem stiku $\mathrm{z}$ vojaki, razliko nedvomno zaznali. Večje vprašanje je, ali jih je motila, kot je v svojih spominih desetletja pozneje zapisal Trušnovič. V virih sicer opazimo skrb za vojaško prehrano, včasih častniki poskrbijo za dodaten obrok, redkeje si z vojaki delijo svojo ali skupaj pripravljeno hrano. Toda to so bile izjeme, ki hierarhije pri prehranjevanju niso postavljale pod vprašaj. Janko Hacin je zapisal, kako je svojemu slugi "ponudil salamo in košček kruha", nato pa še »dva kosa sira 'Imperial' in kos kruha, majhen sicer«, ker je sluga - "zvest mohamedan« - odklonil salamo. Prav tako je v dnevniku opisal, kako so si častniki njegove enote in vojaki na položaju razdelili pečeno srno, ki jo je ustrelil vojak, vendar je sicer brez slabe vesti užival vse častniške privilegije. ${ }^{76}$ $\mathrm{V}$ trenutkih skupnega prehranjevanja, $\mathrm{v}$ skrbi za vojake, moramo gotovo videti predvsem igranje vloge skrbnega očeta - včasih tudi strah pred nezadovoljnimi vojaki -, ne pa želje po zmanjšanju ali celo ukinitvi razlik. $V$ družbi, kjer so bile »stanu primerne« razlike nekaj običajnega, samoumevnega, česa drugega niti ne moremo pričakovati. ${ }^{77}$ Poleg tega moramo upoštevati, da je pred vojno vojaško vodstvo rezervnim in aktivnim častnikom v glavo vbijalo, da so družbena elita, ki vojakom ukazuje, vendar se z njimi ne druži in se minimalno zanima za njih. ${ }^{78}$ Zato ne preseneča, da je Hacin

73 Max Hastings, Catastrophe 1914: Europe Goes to War (London: William Collins, 2013), 505. O Trušnoviču in njegovem izredno zanimivem življenju sicer: Neža Zajc, "Aleksander Trušnovič, " v: Med domom in svetom, ur. Igor Grdina (Ljubljana: Založba ZRC, 2011), 263-79. O razlikah med častniki in vojaki gl. tudi Hämmerle, »Opferhelden?, «174-75. Hameršak, Tamna strana, 510.

74 Zgodovinski inštitut Milka Kosa, ZRC SAZU, „Dnevnik škofa Jegliča, tipkopisni prepis, zv. 9, 71 (vpis za 17. januar 1917).

75 Duffet, Stomach, 1-2.

76 Hacin, Vsi ti mladi fantje, 40, 142-43.

77 Duffet, Stomach, 9, 41-42, 139-40, 158-59, 175-77, 221. Britanske prakse, ko so se za božič vloge obrnile, in so častniki stregli vojakom, v slovenskih virih ne najdemo.

78 István Deák, Der k.(u.)k. Offizier: 1848-1918, prev. Marie-Therese Pitner, 2. izd. (Wien, Köln, Weimar: Böhlau, 1995), 126-28. Za osvetlitev odnosa častnikov do vojakov je zelo pomembna novejša knjiga Christe Hämmerle, ki poleg spremne študije prinaša tudi serijo izredno dragocenih spominskih zapisov predvojnih navadnih vojakov: Christa Hämmerle, ur., Des Kaisers Knechte: Erinnerungen an die Rekrutenzeit im k. (u.) k. Heer 1868 bis 1914, Damit es nicht verlorengeht ..., 66 (Wien, Köln, Weimar: Böhlau, 2012). Gl. tudi: Christa Hämmerle, »'... dort wurden wir dressiert und sekiert und geschlagen ...': Vom Drill, dem Disziplinarstrafrecht und Soldatenmisshandlungen im Heer (1868 bis 1914), « v: Glanz - Gewalt - Gehorsam: Militär und Gesellschaft in der Habsburgermonarchie (1800 bis 1918), ur. 
brez vsakršne slabe vesti kot povzetek neproblematične prakse v dnevnik napisal: »Ko je moštvo pojedlo, smo šli tudi mi večerjat izborno riževo juho in bržolo s praženim krompirjem in palačinke, izdelek našega četovodje Voleka. «79

Izpričano vojaško negodovanje zaradi neenakosti je večkrat preglasilo skupno sovraštvo vojakov, podčastnikov in častnikov s fronte do vseh drugih v vojski. V avstro-ogrski armadi - pa tudi v vseh drugih - je le redko kdo znal povedati kaj prijaznega o Etappenschweine, "svinjah iz zaledja«. Pri frontnih častnikih ni mogoče spregledati zgražanja nad resničnimi ali namišljenimi privilegiji zalednih. Večkrat omenjeni Janko Hacin je pogosto kritiziral razlike, njegov facit pa dobro povzema prevladujoče mnenje: "Sploh je žalostna resnica, da vsa poveljstva od prapora gori izborno živijo, kar zadeva hrano, bolje nego v miru, medtem ko se nam nižjim ne godi ravno dobro. ${ }^{80}$ Vojaki so negodovali nad kuharji, bolničarji in vozniki oskrbnih vozov, posebej osovraženi pa so bili častniški sluge. Ni mogoče zanikati, da so bile te kategorije vojakov praviloma bolje prehranjene, saj so bili zaradi svoje službe bližje hrani, tako rekoč "pri koritu«. Prav tako so izpričani številni primeri namernih zlorab. A vojaki iz jarkov so spregledovali ali minimizirali pomen zalednih služb in tveganja, ki so jim bili izpostavljeni bolničarji, nosači hrane in vojaki pri transportu. Že citirana odlomka iz Malgajevega dnevnika - "Zgodilo se je, da so nam ... pobili tovorno živino, ki nam je ponoči prinašala proviant « - in spominov poljskega vojaka - „Bila so tudi taka obdobja, da po tri dni nismo nič jedli, ker so po poti umrli ti, ki so šli po hrano« opozarjata, da so tudi vojaki, ki niso bili na prvi frontni liniji, bili premraženi, žejni in lačni ter da so tudi oni umirali. Rudolf Lampič, ki je sredi leta 1917 nekaj časa nosil hrano na bojno linijo na Sv. Gabrijelu, je svojo izkušnjo povzel: »Prostovoljno, zase, jo ne bi šel iskat nikoli v takem času, rajši bi ostal tudi cel teden brez nje. ${ }^{81}$

Jasno je torej, da je bilo doživljanje odvisno tudi od percepcije posameznika. Občutne razlike $\mathrm{v}$ količini in kvaliteti hrane, ki so jo na fronti dobivali vojaki in častniki, in razlike $v$ načinu prehranjevanja - častniki so pogosteje kot vojaki imeli mizo, namizno posodje in pribor - so bile mnogokrat ignorirane, saj je prevladal občutek povezanosti v skupni nesreči. Stiske zalednikov pa so bile spregledane, ker so bili izključeni iz skupnosti frontnih bojevnikov.

\section{Vpliv individualnih okoliščin na izkušnjo}

Izkušnje so bile tudi sicer odvisne od individualnih značilnosti in konteksta. Lakota in slaba hrana namreč nista povsem objektivni kategoriji, ampak sta odvisni od

Laurence Cole, Christa Hämmerle in Martin Scheutz, Frieden und Krieg: Beiträge zur Historischen Friedensforschung, 18 (Essen: Klartext, 2011), 31-54.

79 Hacin, Vsi ti mladi fantje, 64.

80 Ibid., 101. V Malgajevi zapuščini je ohranjena ena izmed zbadljivih pesmic, ki so o »etapnih prašičih« krožile po jarkih. - Malgaj, Vojni spomini, 191. Za Nemce in Britance gl.: Lummel, „Food Provisioning in the German Army,«16. Duffet, 134-37 in passim.

81 Rudolf Lampič, »Moja pot v svetovni vojni, « neobjavljen tipkopis, 77, pridobljeno 3. 9. 2015, http://www.dlib.si/?URN=URN:NBN:SI:DOC-ASOGCWT2. 
marsikatere okoliščine. Omenil sem že, da je bila - vsaj v začetku - vojaška hrana za marsikoga zelo pozitivna izkušnja, saj je bila obilnejša od tiste, ki jo je bil navajen doma. Tudi za slovensko prebivalstvo velja, da je bil pred vojno velik delež prebivalstva slabo, celo nezadostno prehranjen. Gorazd Makarovič v edini meni znani raziskavi ugotavlja: "Iz vsega povedanega je mogoče sklepati, da so (razen zgornjih družbenih plasti), v vseh ozirih zadostno prehrano imeli le na velikih kmetijah; ostalo prebivalstvo pa se je večinoma hranilo nezadostno glede na potrebne gradbene in energetske snovi; del prebivalstva je živel $\mathrm{v}$ hudem pomanjkanju in kroničnem stradežu. «82 Pričakovano je torej, da je bila percepcija zadostne prehrane zelo odvisna od socialnega položaja vojakov. 83

Toda upoštevati je treba tudi, da so bili moški v družini pogosto privilegirani pri prehranjevanju, dobivali so največ hrane in najboljšo, medtem ko v masovni vojski takšne pozicije niso imeli, kar je gotovo vplivalo na njihovo doživljanje vojaških obrokov. ${ }^{84} \mathrm{~K}$ temu je treba dodati še navajenost na določene vrste hrane. Slovenski vojaki avstro-ogrske vojske so pred vojno jedli zelo različno, pač glede na socialni položaj in regijo, iz katere so prihajali. Mnogi so za seboj sicer že imeli nekajletno vojaško služenje, tako da vojaška hrana in skupno prehranjevanje zanje nista bila povsem nova izkušnja, toda $\mathrm{v}$ vojnih razmerah so se morali privaditi še marsičemu. Ker neznana hrana in nenavadne kombinacije pogosto vzbujajo odpore, je bilo tudi to lahko razlog za nezadovoljstvo. Rek, da je »lakota najboljši kuhar«, v grobem gotovo drži, a v zgodovini poznamo primere, ko so vojaki zavračali neznano, zanje nenavadno hrano, tudi ko so bili lačni, v ekstremnih primerih celo, ko so stradali. ${ }^{85}$ Česa takšnega v slovenskih virih nisem našel, pogosto pa se pojavlja negodovanje nad hrano iz pločevink, ki gotovo ni bila kulinarični užitek, a je imela energijsko vrednost. Jakob Prešeren, vojak v pehoti, je pomladi leta 1916 zapisal, da njegov želodec „kljub vsej sestradanosti ... konzerv ne prenaša več« in skupaj z drugimi, ki so tudi imeli podobne pripombe, potrdil, da sta bila pomembna tudi videz in okus hrane, ne samo njena kalorična vrednost. ${ }^{86}$

Avstro-ogrska vojska je sicer poskušala upoštevati nekatere partikularizme - seveda je spoštovala verske predpise -, nekaj občutljivosti so pokazali tudi posamezni poveljniki, vendar je imela vojaška fleksibilnost svoje meje. ${ }^{87}$ Ključne so bile vendarle kalorije, medtem ko je bilo v zelo heterogeni vojski navad in posebnosti neobvladljivo veliko. Odlomek iz neobjavljenih spominov Franza Xaverja Schuberta jih lepo ilustrira: "Sicer pa Huculov ni bilo enostavno navaditi na okus mesa, ki ga niso bili

82 Gorazd Makarovič, "Prehrana v 19. stoletju na Slovenskem, "Slovenski etnograf 33/34 (1988/1990): 157.

83 Wilcox, "Tra testo e corpo, 35.

84 Roman Sandgruber, Frauensachen - Männerdinge: Eine "sächliche" Geschichte der zwei Geschlechter (Wien: Ueberreuter, 2006), 25-45. Duffet, Stomach, 46-47, 88.

85 Duffet, Stomach, 55-56, 67-68, 150-51.

86 Jakob Prešeren, Vojak 1915-1918 (Celje: Celjska Mohorjeva družba, 2014), 102.

87 Brandauer, Menschenmaterial Soldat, 213 
vajeni. Redki Čehi pa so vedno znova hoteli 'knedle', ki so jih Rutenci zavračali. ${ }^{88}$

$\mathrm{Ob}$ tem je nekatere vznemirjal ali tolažil način prehranjevanja. Motilo jih je prerivanje in "necivilizirano" prehranjevanje z rokami. Posebno ob praznikih, vendar ne le takrat, so se vojaki in častniki trudili ustvariti boljše pogoje, bolj »domače« okolje. Pri tem je šlo predvsem za približke meščanskim idealom. Franc Rueh je s Tirolske maja 1917 svoji ženi pisal: »Naredili smo si prav lepo sobo, v kateri ima nekaj oficirjev svojo 'Offmesse'. Sedimo pri pogrnjeni mizi, pijemo kavo iz porcelanastih skledic, vino iz lepih kozarcev. Seveda dobimo vsega le predpisano porcijo - ali imamo dovolj in pa - kar tudi ni zadnje - v lepi obliki.« 89

Tako kot okolje je bilo pomembno tudi počutje. Intenzivni spopadi niso le oteževali dostave hrane, ampak so vojakom praviloma zmanjšali apetit. Kljub temu da so porabili veliko energije in bi morali temu primerno jesti, mnogi niso čutili lakote. Že po začetnih bojih v Galiciji je Lorenc Prestor zapisal, da je bilo to »tako klanje, da sploh ne pomisliš več ne na dom ne na prijatle [sic] in nisi ne lačen ne žejen«, Janko Hacin pa je bil med hudimi zimskimi boji "tako nervozen, da [ni] mogel večerjati, razen pol krožnika juhe.«90

Skorajda samoumevno je, da je tek pokvarila bolezen, kar se je recimo zgodilo Rudolfu Lampiču. "Nekega dne se mi ustavi menaža, ki sem se jo drugače vedno tako veselil«, je zapisal in nadaljeval: „Vse me je bolelo, da se mi ni prav nič ljubilo. Drugi dan je bilo še hujše, prišla je še griža, da sem moral na bolniški pregled. Aspirin, 2 dni službe prost in juha brez mesa, so bila zdravila. Tri dni nisem jedel prav nič, potem je pa že šlo na boljše. Po nekaj dneh mi je pa že šla hrana zopet v tek, še bolj kot prej. «11 Bolezni, povezane s prebavo, bi si sploh zaslužile posebno obravnavo, posebno zato, ker se v slovenskih avtobiografskih virih razmeroma redko pojavljajo, so pa sicer stalnica vojskovanja. Se je piscem zdelo, da se o tem ne spodobi pisati, ali so vzroki kje drugje, je vsekakor vprašanje, na katerega bi veljalo v prihodnje odgovoriti.

Janku Hacinu, ki je na vzhodnem bojišču prisostvoval ustrelitvi dezerterja, je dogodek tudi pokvaril tek. "Mnogo dobrih stvari, ki nam jih je ... pripeljal četovodja Marinković, nam je zato mnogo manj teknilo«, je zapisal in potrdil, da psihološko stanje pomembno vpliva na izkušnje, povezane $s$ hrano. ${ }^{92}$ Seveda pa še tako dobro razpoloženje ni moglo nadomestiti občutnega pomanjkanja hrane. Lakoto lahko občutimo prej ali pozneje, toda v prenizkem energijskem vnosu ni prav nič subjektivnega. $S$ trajanjem vojne pa je pomanjkanje kalorij za vojake postajalo vse večji problem. Na eni strani je bilo hrano vse težje dobiti, čeprav je imela armada prednost

88 Originalni tekst se glasi: "Übrigens war es nicht leicht, die Huzulen an den ungewohnten Fleischgenuss zu gewöhnen. Und die wenigen Tschechen wollten immer wieder 'Knedli', die von den Ruthenen abgelehnt wurden." - Österreichisches Staatsarchiv, Kriegsarchiv, Nachlässe und Sammlungen, NL B /833, nr. 2, Franz Xaver Schubert, "Tagebuch : aus losen kurz nach dem Erlebnis verfassten Tagebuchblättern 1943 zusammengestellt und ergänzt, « neobjavljen tipkopis, fol. 49. Odlomek mi je posredovala Tamara Scheer, za kar se ji najlepše zahvaljujem.

89 Rueh, Moj dnevnik, 131. Duffet, Stomach, 85-89, 157.

90 Luthar, O žalosti, 128. Hacin, Vsi ti mladi fantje, 111. Tudi Duffet, Stomach, 172-73.

91 Lampič, »Moja pot, «30.

92 Hacin, Vsi ti mladi fantje, 81. 
pred civilnim prebivalstvom, na drugi pa so se povečevali logistični izzivi, saj je bilo transportno omrežje vse bolj iztrošeno.

\section{Poslabševanje oskrbe in lakota}

V Avstro-Ogrski so se prvi problemi pokazali že ob koncu leta 1914, ko je prišlo do pomanjkanja žit, leta 1915 so bile potrebne omejitve pri mesu. ${ }^{93}$ Pozneje se je položaj samo še slabšal. Predvsem v zadnjih treh letih vojne se je vidno poslabševala tudi preskrba vojske. Sredi leta 1915 lahko v dnevniku Franca Zupančiča še beremo o nenehnih »veselicah", ki niso bile rezervirane le za častnike, za božič istega leta Ivan Primožič ni samo dobro jedel, temveč je tudi pil "Gumpoldskirchnerja in šampanjca«, navadni vojak Franc Reberšek pa je oktobra domačim sporočil: „Stradav [sic] dosedaj še nisem. «94 Pozneje je postalo pomanjkanje vse bolj očitno, in sicer tudi za privilegirane častnike. Naslednje leto je Primožič za božič uspel dobiti le steklenico piva in slabega likerja ter »eno limono, malo smrdljive klobase, malo slanine, malo meda, malo kolača». ${ }^{95}$

Michał Janik, poljski zgodovinar, ki je analiziral spomine vojakov iz Galicije, ugotavlja, da »od leta 1916 vsa poročila enoglasno navajajo, da so vojaki vedno slabše oskrbljeni in da jih tare lakota", podobne so ugotovitve drugih avtorjev in potrjuje jih analiza slovenskih virov. ${ }^{96} \mathrm{~K}$ lakoti ni prispevalo samo pomanjkanje hrane, ampak tudi naraščajoče težave s transportom. Vse več je bilo tudi problemov s preobremenjeno opremo za pripravo hrane, saj je ni bilo mogoče zamenjati, ker je primanjkovalo tako surovin kot delovne sile. ${ }^{97}$ Jakob Prešeren je dan po veliki noči leta 1916 napisal:

Preživljamo praznike, zraven pa stradamo. Včeraj ni bilo ne kruha, ne kosila, pač pa so nam dovolili, da za kosilo lahko pojemo vsak po eno rezervno porcijo prepečenca in eno celo konzervo. ... Vendar pa je vojaštvo civilistom izpraznilo vse zaloge, tako da se niti za denar ničesar več ne dobi. Želodec nam poje kot gramofon s pokvarjeno ploščo.

Teden kasneje pa je dodal:

Vsak tretji dan dobivamo dnevno porcijo kruha za dan nazaj, zraven pa še po 5 dekagramov prepečenca. Enako vsak tretji dan nekaj govedine, ostale dni pa žvečimo konzerve ... Zato se tudi širijo govorice, da ofenzive morda ne bo, ker sestradanih ljudi ni mogoče uspešno goniti nad sovražnika. ${ }^{98}$

93 Rauchensteiner, Der Tod des Doppeladlers, 143-44.

94 Zupančič, Dnevnik, 26-28. Luthar, $O$ žalosti, 154. Reberšek, "Pisma slovenskega vojaka, «779.

95 Luthar, $O$ žalosti, 168.

96 Janik, »Front Soczy«. Hämmerle, »Opferhelden?,« 174. Brandauer, Menschenmaterial Soldat, 217-19.

97 Brandauer, Menschenmaterial Soldat, 209.

98 Prešeren, Vojak 1915-1918, 101-02. 
Še nekoliko pozneje, decembra 1917, ko je bilo tudi konzerve težko dobiti, se je Jože Hameršak, ki je pred tem pobegnil iz ruskega ujetništva, z nostalgijo spominjal izobilja v Rusiji in zapisal: „Hrana je bila strašno slaba: malo, kuhali so suhe koprive in sploh suho zelenjavo, kruha sem dobil za prst debelo rezino, deset mož je dobilo en komis. Bil sem lačen kot pes. ${ }^{99}$ Pomanjkanje hrane je precej zmanjšalo razlike med vojaki in podčastniki ter častniki. »[Z]večer pred napadom sem kot oficir dobil košček smrdljive klobase, za kruh pa koruzne drobtine, ki sem jih lovil po žepu«, je zapisal Miloš Vauhnik pred začetkom 12. soške bitke, Vinko Gaberc pa je položaj nekaj mesecev pozneje nekoliko privoščljivo komentiral: „Še iz oficirske kuhinje ni več puhal oni blagodiš̌či vonj, ki je krepil gospodi voljo za nadaljevanje vojne, moštvu pa nevoljo in zavist. «100

V zadnjem letu vojne ni bilo mogoče spregledati vse bolj obupnega položaja. Mir z Rusijo ni veliko spremenil in upanje na dobavo ukrajinskega žita je bilo večinoma prazno. Prav tako je le kratek čas trajalo relativno obilje po prodoru v Furlansko nižino v jeseni 1917. Zunanji minister Czernin je v spomenici cesarju Karlu opozarjal: "Omenjam samo pohajanje surovin za strelivo, popolnoma izčrpane zaloge ljudi in zlasti gluhi obup, ki se je zaradi podhranjenosti polastil vseh plasti ljudstva in onemogočil nadaljnje prenašanje vojnega trpljenja... «101 Pomanjkanje je v polni meri prizadelo tudi vojake, čeprav je imela vojska pri oskrbi še vedno prednost. Jeseni 1918 je bila povprečna teža avstrijskega vojaka na italijanski fronti malo nad $50 \mathrm{~kg}$, dosti bolje ni bilo niti na drugih bojiščih. Ciril Prestor je bil malo nad tem katastrofalnim povprečjem, saj je bil " $58 \mathrm{~kg}$ težak «. ${ }^{102}$

Katastrofalnost podatka sicer nekoliko omili upoštevanje nižje povprečne višine tedanjih moških. Prav tako ni dvoma, da so se znotraj teh povprečij skrivale različne zgodbe in da so vojaki, podčastniki in častniki različno dojemali svoj položaj; nekoliko je na oskrbo vplival tudi letni čas. Toda ob upoštevanju vsega tega ni mogoče mimo ugotovitve, da je vojska stradala. Pričevanj je ogromno in skozi vso retoriko, skozi vso subjektivnost, je dobro vidna realnost lakote, ki gotovo ni bila diskurz, ampak dejanska usoda vojakov. Franc Rueh v dnevniku opisuje vojake, ki so prosjačili za hrano, od lakote jokali in bežali, toži pa tudi nad svojim pokvarjenim želodcem. ${ }^{103}$ Jakob Prešeren večinoma piše le še o pomanjkanju hrane in skrajnem obupu vojakov, ki so bili vse bolj prepuščeni sami sebi:

99 Hameršak, Skoz prvo svetovno, 109.

100 Cit. pri: Verginella, „Soška fronta, "53. Vinko V. Gaberc-Gaberski, Brez slave: spomini na svetovno vojno ([Celje]: samozaložba, 1935), 182-83. Tudi ibid., 179.

101 Cit. pri: Feliks J. Bister, Anton Korošec, državnozborski poslanec na Dunaju: življenje in delo, 1872-1918, prev. Janko Moder (Ljubljana: Slovenska matica, 1992), 168.

102 Luthar, O žalosti, 189. Peter Schubert, Piava 1918: Zadnja bitka avstro-ogrske monarhije, prev. Tone Perčič (Celovec, Ljubljana, Dunaj: Mohorjeva družba, 2001), 94. Brandauer, Menschenmaterial Soldat, 220.

103 Rueh, Moj dnevnik, 197-98, 201-02, 212. 
Obup raste in raste in kmalu bo dorastel do skrajnosti. ... klobčič črnega sukanca ... sem zamenjal za liter fižola. Kř̀ž pa je petdeset cigaret zamenjal za kilogram koruzne moke. Zdaj kuhava fižol in polento. Křiž je tako sestradan, da je drobil surov fižol in ga grizel kot bombone, zraven pa lizal surovo moko. Grobo sem ga moral odpoditi, češ, da je to na prazen želodec zelo nezdravo. ${ }^{104}$

Prehranska katastrofa, pomanjkanje oblačil in s tem povezano širjenje bolezni ter neuspeh ofenzive čez Piavo so skupaj s političnim nemirom povzročili zlom morale na italijanskem bojišču v zadnjih mesecih vojne. Kar je zavezniška propaganda neuspešno poskušala doseči vsa leta vojne, se je sedaj začelo dogajati: vojaki so množično zapuščali svoje enote, večinoma so odhajali domov, ali pa se niso vračali z dopusta. Sestradana in napol gola armada se je sesuvala sama vase. ${ }^{105}$ Poskusi, da bi vojake motivirali s patriotično propagando, so imeli minorne učinke, prav tako niso bile prepričljive primerjave s položajem civilne populacije v zaledju. Res so civilisti tudi stradali, posebno v velikih mestih, toda »rezervatni ukazi« o seznanjanju vojakov z njihovim položajem so dosegli malo. Sodba Franca Rueha, „Naj dajo raje vojakom jesti, pa se bojo dobro borili!«, je bila precej realna, čeprav so voljo do boja načenjali tudi drugi dejavniki in se mnogi niti s polnimi želodcem niso bili več pripravljeni boriti. 106

$\mathrm{V}$ splošnem je zavedanje, da se preskrba slabša tudi doma, za civiliste, pomagalo miriti negodovanje, ki je bilo značilno za vojske vseh držav. ${ }^{107}$ Toda mnogi avstro-ogrski vojaki v to, da si z ljudmi v zaledju v vsem delijo usodo, niso preveč verjeli, ampak so bili prepričani, da se vsem godi bolje kot njim. ${ }^{108}$ Zato opominjanje na usodo civilnega prebivalstva ni dosti zaleglo. Pomanjkanje hrane je univerzalen razlog vojaškega nezadovoljstva, v britanski vojski je do izbruha prihajalo ob dosti manjšem pomanjkanju, in tudi v avstro-ogrski vojski ni bilo nič drugače. Besede niso več zadostovale, zaloge patriotizma in potrpežljivosti so bile izčrpane. »Moštvo je postajalo vedno bolj nezadovoljno. Hrana je bila pod ničlo. Bili smo bolj lačni kot siti. Niti enkrat nismo imeli možnosti do sitega se najesti«, je zapisal Jože Hameršak, poleg tega pa tudi: "Moštvo je bilo precej revolucionarno. Samo malo bi bilo treba migniti, pa bi bila zmeda tu. ${ }^{109}$ Armadno vodstvo je nezadovoljstvo poskušalo miriti z vrsto ukrepov, med drugim je oktobra 1918, ko je država pred seboj imela manj

104 Prešeren, Vojak 1915-1918, 343. Sukanec je bilo med vojno težko dobiti in je njegova cena zelo narasla. Natančni Fran Milčinski je novembra 1917 zabeležil, da je cena s 60 hellerjev poskočila na 28 kron, kar je skoraj 50-kratno zvišanje. - Fran Milčinski, Dnevnik 1914-1920, ur. Goran Schmidt (Ljubljana: Slovenska matica, 2000), 298. Tonetu Slodnjaku se zahvaljujem, da me je opozoril na ta pasus v Milčinskijevem dnevniku.

105 Mark Cornwall, The Undermining of Austria-Hungary: The Battle for Hearts and Minds (Houndmills, London, New York: St. Martin's Press, 2000), 405-15.

106 Rueh, Moj dnevnik, 202.

107 Duffet, Stomach, 96-97.

108 Rauchensteiner, Der Tod des Doppeladlers, 598.

109 Hameršak, Skoz prvo svetovno, 138-39. Za Britance: Duffet, Stomach, 73-76, 96-99. 
kot mesec obstoja, napovedalo izenačitev vojaške in častniške prehrane. ${ }^{110}$ Ukrepi niso bili povsem brez učinka, navsezadnje vojska kljub vsem težavam ni razpadla, ampak se je borila do podpisa premirja. Toda vojaški upori v letu 1918, kakor so bili povezani z delavskim gibanjem, prizadevanji za mir in kipečimi nacionalizmi, so bili tudi upori lačnih vojakov. To velja tudi za upore slovenskih vojakov v zaledju v maju in juniju in na bojišču v oktobru. ${ }^{111}$

Omeniti velja, da so težave pri oskrbi s hrano imele vse vojske z izjemo ameriške in da se je kalorična vrednost obrokov zniževala tudi v vojskah antantnih držav. Prav tako so se z omejitvami srečevali civilisti. Predvsem porabo mesa so začeli povsod hitro racionirati. Britanska vojska je začetno normo, $4.200 \mathrm{kcal}$, hitro zmanjšala in začela vojake deliti na različne kategorije, tako da so najboljšo hrano dobivali le na fronti. Toda kot minimum je določila še vedno spodobnih $3.000 \mathrm{kcal} .{ }^{112} \mathrm{~V}$ praksi seveda logistika ni vedno držala koraka s potrebami in tudi britanski vojaki so bili kdaj lačni, toda to so bila kratka obdobja. Normative so zmanjševali tudi v italijanski vojski, kjer so včasih prav tako imeli težave z redno in pravočasno oskrbo. A v slovenskih avtobiografskih zapiskih pogosto naletimo na pasuse, ki omenjajo obilje hrane pri italijanskih vojakih, kar pomeni, da je bila italijanska prehrana vsaj v razmerju z avstrijsko zelo solidna. Razen tega so po porazu pri Kobaridu za enega temeljev obnove morale $\mathrm{v}$ vojski postavili prav boljšo in izdatnejšo hrano ter so norme spet dvignili. Poskrbeli so tudi, da so vojaki v neposrednem zaledju fronte lahko kupovali dodatno hrano. ${ }^{113}$

Seveda ne moremo spregledati, da so antantne države imele dostop do večjih kapacitet, in sicer ne samo v svojih državah in v kolonijah ter dominionih, ampak tudi v nevtralnih državah. Ampak v primerjavi z Avstro-Ogrsko je bila prehranjenost vojakov boljša tudi v Nemčiji, ki je bila v enakem položaju. Nemci so se vojaški lakoti v veliki meri izognili, čeprav se je oskrba $\mathrm{v}$ nemški vojski močno poslabšala in je civilno prebivalstvo $v$ Nemčiji stradalo. ${ }^{114}$ A odgovor na vprašanje, zakaj je do takšnih težav z oskrbo $s$ hrano prišlo prav v avstro-ogrski armadi, pustimo za kakšno drugo priložnost.

\section{Vojaška samopomoč, pomoč svojcev}

Za konec raje poglejmo še en pomemben aspekt. Ne smemo namreč pozabiti, da sta ob vseh pomanjkljivostih armadne oskrbe $s$ hrano, sploh ob njenem zlomu na koncu vojne, toliko bolj do izraza prišli iznajdljivost in samoiniciativnost vojakov in častnikov. Viri kažejo, da ju ni manjkalo. Čeprav mogoče nista prinesli sitosti, ampak sta predstavljali le razliko med večjo ali manjšo lakoto, sta gotovo vredni analize.

110 Rauchensteiner, Der Tod des Doppeladlers, 598.

111 Lojze Ude, »Upori slovenskega vojaštva v avstro-ogrski armadi, « Zgodovinski časopis 22, št. 3-4 (1968): 185-205, predvsem pa 196.

112 Duffet, Stomach, 78-79, 123.

113 Wilcox, »Tra testo e corpo, «35. Thompson, The White War, 331.

114 Lummel, »Food Provisioning in the German Army, 20, 23. 
Vojaki so tudi v predhodnih vojnah pogosto morali sami poskrbeti za hrano in se niso mogli zanesti na vojaško logistiko. Pri tem se je pokazalo, da so bili praviloma v boljši situaciji vojaki, ki so si že v civilnem življenju nabrali nekaj izkušenj s samopreskrbo. Med krimsko vojno so bili tako iniciativnejši francoski vojaki, ki so večinoma prihajali s kmetov, medtem ko so jo slabše odnesli britanski, po večini reveži iz urbanih okolij. Francozi so vedeli, kaj je mogoče pojesti, z veseljem so pojedli tudi kakšno žabo, znali so loviti divjad in ribe, Britanci pa teh znanj v glavnem niso imeli. ${ }^{115} \mathrm{~A}$ tudi med urbanim prebivalstvom so bile razlike: $\mathrm{v} 1$. svetovni vojni so $\mathrm{v}$ britanski armadi največ iznajdljivosti pokazali vojaki, ki so rastli v revščini, saj so že kdaj prosili za hrano, znali so si jo tudi priskrbeti z nabiranjem plodov ali krajo na poljih. ${ }^{116}$

$S$ te perspektive je imela večina slovenskih vojakov kar srečo, saj so prihajali s podeželja in so imeli številne potrebne spretnosti, pa tudi nekateri meščani so pokazali sposobnost hitrega učenja. Franc Zupančič, geometer, ki je od začetka študija živel v mestih, se je na primer naučil ribolova z eksplozivom, kar je bila tudi sicer precej razširjena praksa. ${ }^{117}$ Poleg tega so vojaki ujeli kakšno srno, jedli žabe, nabirali sadje in divja zelišča, prav je prišel, kot piše Rudolf Lampič, tudi »košati kostanj nad jarkom, od katerega je zreli sad padal k nam. «118 Tisti brez predsodkov pa so si privoščili celo "pasjo ali lisičjo pečenko". Aleksander Ličan uživanje pasjega in mačjega mesa ter celo mrhovine omenja že v letih 1914/15, med štiri in pol mesečnim obleganjem Przemyśla. ${ }^{119}$ Spet pa je praksa postala aktualna z zaostritvijo prehranskega položaja in Lampič brez zadržkov prizna, da so tik pred koncem vojne:

pospravili precej psov, nekega dne pa posebno velikega. Kakor so me izvolili za kuha [sic], tako so me tudi zdaj za mesarja. Prav velik čebriček je bilo samega mesa, ki se je pozneje kuhal in pražil v naših loncih. ${ }^{120}$

Tudi številne mačke so takrat končale $\mathrm{v}$ vojaških želodcih, čeprav je slovenski stereotip uživanje mačjega mesa pripisoval zahodnim sosedom. Medtem ko je Ciril Prestor zgroženo zapisal, da Italijani jedo "večinoma polento, mačje meso, podganjo mast«, je Vinko Gaberc v svojih spominih priznal, da slovenski vojaki niso jedli samo psov, ampak tudi mačke, čeprav jih je bilo težje loviti: »Pse so naši vojščaki svobodno pobijali in si jih pripravljali kot dodatek k nezadostni menaži. Mačka pa se drži bolj doma in često je bilo treba zvijače, da si jo pahnil v nesrečo. «121

115 Orlando Figes, The Crimean War: A History (2010; New York: Metropolitan Books, 2011), 289-90.

116 Duffet, Stomach, 55, 210-15.

117 Zupančič, Dnevnik, 66,-67. Ribolov "z ekrazitom» omenja tudi: Lampič, "Moja pot,« 81. Različne vrste ribolova pogosto omenjajo hrvaški viri: Hameršak, Tamna strana, 510.

118 Hacin, Vsi ti mladi fantje, 142-43. Gaberc-Gaberski, Brez slave, 183. Prešeren, Vojak, 337. Lampič, »Moja pot,« 64.

119 Aleksander Ličan, Spomini iz Sibirije (Ilirska Bistrica: Društvo za krajevno zgodovino in kulturo, 2006), 18.

120 Lampič, "Moja pot, 95.

121 Luthar, O žalosti, 186. Gaberc-Gaberski, Brez slave, 184. 
Poleg nabiranja in lova je bil običajen način samooskrbe tudi kraja. Vojaki so hrano kradli pogosto, in sicer tako iz vojaških zalog kot tudi od civilistov. Pred lačnimi vojaki zlasti niso bila varna zapuščena poslopja in polja, katerih lastniki so se morali umakniti z bojišča. Čeprav je bil to hud prekršek zoper vojaško tovarištvo, so kradli tudi drugim vojakom. To je bilo sicer posebno tvegano, saj je bilo razširjeno prepričanje, da si - kot je zapisal Rudolf Lampič - »sobojevnik, ki krade svojemu sotrpinu, ne zasluži drugega ko kroglo«, vendar kljub temu dovolj pogosto. ${ }^{122}$

Kot smo videli, so vojaki do hrane prišli tudi z zamenjavo, pogosto so jo delili med seboj, altruistični vojaki so bili posebno cenjeni, dokler je bilo mogoče, so kaj kupili, če so le imeli denar. Posebno častniki so pogosto hodili v gostilne ali z nakupi obogatili svoj meni, toda kupovali so tudi vojaki.

Ko se zjutraj zbudim, mi zadiši svež kruh. Ker posebno siti nismo bili, se začnem zanimati, kje je pekarna. Pogledam skoz ograjo čez sadni vrt proti hiši, pa vidim, da ženske nakladajo kruh v razne torbe. Torej je v tej hiši pekarna. Takoj preskočim ograjo, grem v pekarno in kupim par štručk ravno iz peči vzetega kruha,

je dogodek iz sredine leta 1915 opisal Jože Hameršak. ${ }^{123}$

Zelo pomembne so bile pošiljke od doma, ki niso bile le obogatitev vojaškega jedilnika, ampak so imele tudi močno emocionalno komponento. Predstavljale so materialni dokaz skrbi domačih za svojega vojaka. Tudi zato so vojaki v pismih pogosto prosili za hrano. ${ }^{124} \mathrm{~S}$ potekom vojne pa je v ospredje vse bolj prihajala kalorična vrednost pošiljk. Čeprav so postale manj bogate, saj je hrane v glavnem primanjkovalo tudi domačim, so marsikateremu prejemniku olajšale hudo lakoto. Jakob Prešeren je proti koncu vojne z velikim upanjem pričakoval »dva kosa kruha in klobaso«, ki so ju poslali njegovi, in v njegovem položaju je skromna pošiljka verjetno pomenila več kot "zaboj ... poln slaščic«, ki ga je v začetku leta 1915 dobil Janko Hacin. ${ }^{125}$ Tudi tega, da Franca Reberška ni motila nekoliko plesniva - "pa do škode pa šene [sic] « - pošiljka, ampak mu je prišla »zelo prav«, najbrž ne moremo pripisati le njegovi neizbirčnosti, ampak predvsem pomanjkanju alternativ. ${ }^{126}$

$\mathrm{Na}$ koncu ne smemo pozabiti niti na tobak. Tematika kajenja in oskrbe s tobakom si sploh zasluži temeljito obdelavo, toda na tem mestu ga omenim samo kot način blaženja lakote. O tem v virih ni malo podatkov in brez dvom je marsikateri vojak s kajenjem poskušal pregnati lakoto. »Po navadi kadimo cigareto za cigareto ..., da bi pozabili na ljubi prazni želodec«, je v dnevnik junija 1916 zapisal Karel Jagodič. ${ }^{127}$

\footnotetext{
122 Lampič, »Moja pot, « 33.

123 Hameršak, Skoz prvo svetovno, 12.

124 Brandauer, Menschenmaterial Soldat, 217-18.

125 Prešeren, Vojak, 343. Hacin, Vsi ti mladi fantje, 78.

126 Reberšek, "Pisma slovenskega vojaka, 799.

127 Jagodič, »Med življenjem in smrtjo, «696-97.
} 


\section{Sklep}

Kot vse druge je tudi izkušnje slovenskih vojakov s prehrano nemogoče reducirati na nekaj enostavnih pripovedi. Ne samo da viri ne povedo vsega, ker so fragmentarni, ampak so bile izkušnje v podrobnostih izredno heterogene, saj so jih sooblikovali mnogi dejavniki. Delovanje logistike, razpoložljivost hrane, vreme, lokacija, čas, razpoloženje in številni drugi faktorji so vplivali na to, ali je posamezni vojak, častnik ali podčastnik dobil dovolj hrane za nadomestitev porabljene energije. Prav tako so vplivali na to, kako je doživljal ta aspekt svojega sodelovanja v 1 . svetovni vojni.

Kljub temu je mogoče oblikovati nekaj ugotovitev, ki imajo precej splošno veljavo. Gotovo lahko rečemo, da je na doživetje prav vseh vplivalo pomanjkanje, ki se je $s$ potekom vojne povečevalo. Vsi ga niso doživeli v polni meri, toda malokdo je bil v začetku vojne slabše prehranjen kot ob njenem koncu. Pomanjkanje hrane in lakota sta bili torej precej splošni izkušnji tako vojakov kot tudi civilnega prebivalstva. Vojaško izkušnjo velike večine je poleg tega zaznamovala nezanesljivost oskrbe. V obdobjih, ko je bilo hrane sicer vsaj za silo dovolj, je namreč prav tako prihajalo do krajših in daljših pomanjkanj. Vojaki so jih poskušali prebroditi na različne načine, rečemo pa lahko, da so po večini pokazali precejšno mero iznajdljivosti.

$\mathrm{Z}$ nadaljnjim raziskovanjem, virov je namreč še ogromno, bo te ugotovitve mogoče znova preveriti in dopolniti. Vsekakor lahko računamo, da bo tako nastala podoba preteklosti, ki ne bo nič enostavnejša, ampak kvečjemu še bolj zapletena, bolj polna podrobnosti, ki tokrat še niso našle mesta v njej.

\section{Viri in literatura}

Literatura:

- Bister, Feliks J. Anton Korošec, državnozborski poslanec na Dunaju: življenje in delo, 1872-1918. Prev. Janko Moder. Ljubljana: Slovenska matica, 1992.

- Bobič, Pavlina. "V dolini smrtnih senc: vera kot zatočišče slovenskega vojaka."V: Velika vojna in Slovenci: 1914-1918, ur. Peter Vodopivec in Katja Kleindienst, 128-40. Ljubljana: Slovenska matica, 2005.

- Bobič, Pavlina. Vojna in vera: Katoliška Cerkev na Slovenskem, 1914-1918. Prev. Niki Neubauer. Celje: Celjska Mohorjeva družba, 2014.

- Bond, Brian. The Unquiet Western Front: Britain's Role in Literature and History. Cambridge, New York: Cambridge University Press, 2002.

- Brandauer, Isabelle. Menschenmaterial Soldat: Alltagsleben an der Dolomitenfront im Ersten Weltkrieg 1915-1917. Innsbruck: Golf, 2007.

- Bourke, Joanna. An Intimate Histoy of Killing: Face-to-Face Killing in the Twentieth-Century Warfare. 1999. Ponatis, London: Basic Books, 2000.

- Colja, Dejan. „Vojaške železnice v naših krajih.«V: Črni Vrh pod Avstro-Ogrsko, 145-72. Črni Vrh nad Idrijo: samozaložba, 2014.

- Cornwall, Mark. The Undermining of Austria-Hungary: The Battle for Hearts and Minds. Houndmills, London, New York: St. Martin's Press, 2000.

- Dawson, Graham. Soldier Heroes: British Adventure, Empire and the Imagining of Masculinities. London, New York: Psychology Press, 1994.

- Deák, István. Der k.(u.)k. Offizier: 1848-1918. Prev. Marie-Therese Pitner, 2. izd. Wien, Köln, Weimar: Böhlau, 1995. 
- Dentoni, Maria Concetta. »Food and Nutrition (Italy).»V: 1914-1918-online. International Encyclopedia of the First World War. http://encyclopedia.1914-1918-online.net/article/food_and_nutrition_italy.

- Duffet, Rachel. The Stomach for Fighting: Food and the Soldiers of the Great War, Cultural History of Modern War. Manchester, New York: Manchester University Press, 2012.

- Duffet, Rachel, Ina Zweiniger-Bargielowska in Alain Drouard, ur. Food and War in Twentieth Century Europe. Farnham: Ashgate, 2011.

- Engle, Jason C. »'This Monstrous Front Will Devour Us All?' The Austro-Hungarian Soldier Experience, 1914-15.« V: 1914: Austria-Hungary, the Origins, and the First Year of World War I, ur. Günter Bischof, Ferdinand Karlhofer in Samuel R. Williamson, Jr., Contemporary Austrian Studies, 23, 145-64. New Orleans, Innsbruck: Uno Press, Innnsbruck University Press, 2014.

- Evans, Richard J. In Defence of History, 2. izd. London: Granta, 2000.

- Figes, Orlando. The Crimean War: A History. 2010. Ponatis, New York: Metropolitan Books, 2011.

- Fussell, Paul. Velika vojna in moderni spomin. Prev. Kostja Žižek in Katja Jenčič. Ljubljana: Studia Humanitatis, 2013.

- Godina Golija, Maja. »Hunger and Misery: The Influence of the First World War on the Diet of Slovenian Civilians." V: Food and War in Twentieth Century Europe, ur. Rachel Duffet, Ina Zweiniger-Bargielowska in Alain Drouard, 85-97. Farnham: Ashgate, 2011.

- Godina Golija, Maja. »Recepti in napotki za krizne čase: Primer slovenskega ozemlja med prvo svetovno vojno.« Etnolog 22 (2012): 65-80.

- Hameršak, Filip. Tamna strana Marsa: Hrvatska autobiografija i Prvi svetski rat. Zagreb: Naklada Ljevak, 2013.

- Hämmerle, Christa. Des Kaisers Knechte: Erinnerungen an die Rekrutenzeit im k. (u.) k. Heer 1868 bis 1914, Damit es nicht verlorengeht ..., 66. Wien, Köln, Weimar: Böhlau, 2012.

- Hämmerle, Christa. »'... dort wurden wir dressiert und sekiert und geschlagen ...' : Vom Drill, dem Disziplinarstrafrecht und Soldatenmisshandlungen im Heer (1868 bis 1914). "V: Glanz - GewaltGehorsam: Militär und Gesellschaft in der Habsburgermonarchie (1800 bis 1918), Frieden und Krieg: Beiträge zur Historischen Friedensforschung, 18, ur. Laurence Cole, Christa Hämmerle in Martin Scheutz, 31-54. Essen: Klartext, 2011.

- Hämmerle, Christa. „Opferhelden? Zur Geschichte der k. u. k. Soldaten an der Südwestfront.«V: Krieg in den Alpen: Österreich-Ungarn und Italien im Ersten Weltkrieg 1914-1918, ur. Nicola Labanca in Oswald Überegger, 155-80. Wien, Köln, Weimar: Böhlau, 2015.

- Hastings, Max. Catastrophe 1914: Europe Goes to War. London: William Collins, 2013.

- Human Performance Resource Center, ur., Warfighter Nutrition Guide. http://hprc-online.org/nutrition/warfighter-nutrition-guide-chapter-2-1/WFNutritionGuide2.pdf.

- Janik, Michał. »Front Soczy w relacjach i wspomnieniach Polaków,« neobjavljen referat s simpozija W Galicji i nad Socza : Polacy i Stoweńcy na frontach I wojny światowej, Krakov, 29. -30. maj 2014.

- Keegan, John. A History of Warfare. 1993. Ponatis, London: Pimlico, 1994.

- Kranjc, Gregor Joseph. »The Neglected War: The Memory of World War I in Slovenia." The Journal of Slavic Military Studies 22 (2009): 208-35.

- Kumar, Stane. »Vojaške železnice na Slovenskem.«Kronika 33, št. 1 (1985): 58-61.

- Leidinger, Hannes in Verena Moritz. Gefangenschaft, Revolution, Heimkehr: die Bedeutung der Kriegsgefangenenproblematik für die Geschichte des Kommunismus in Mittel- und Osteuropa 1917-1920. Wien, Köln, Weimar: Böhlau, 2003.

- Lukan, Walter. „Die politische Meinung der slowenischen Bevölkerung 1917/18 im Spiegel der Zensurberichte des Gemeinsamen Zentralnachweisbureaus für Kriegsgefangene in Wien: (mit besonderer Berücksichtigung des Verfassers der Berichte - Milan Hodža)."V: Nationalismus, Gesellschaft und Kultur in Mitteleuropa im 19. und 20. Jahrhundert: Festschrift für Jiř̀ Koralka zum 75. Geburtstag = Nacionalismus, společnost a kultura ve střední Evropě 19. a 20. století: Pocta Jirímu Koralkovi k 75. narozeninám, ur. Jiří Pokorný, Luboš Velek in Alice Velková, 217-83. Praha: Karolinum, 2007.

- Lukan, Walter. "Zgodovinopisje o prvi svetovni vojni.« V: Velika vojna in Slovenci: 1914-1918, ur. Peter Vodopivec in Katja Kleindienst, 16-34. Ljubljana: Slovenska matica, 2005. 
- Lummel, Peter. "Food Provisioning in the German Army of the First World War.« V: Food and War in Twentieth Century Europe, ur. Rachel Duffet, Ina Zweiniger-Bargielowska in Alain Drouard, 13-25. Farnham: Ashgate, 2011.

- Luthar, Oto. "O žalosti niti besede«: Uvod v kulturno zgodovino vélike vojne. Ljubljana: Založba ZRC, 2000.

- Makarovič, Gorazd. »Prehrana v 19. stoletju na Slovenskem.«Slovenski etnograf 33/34 (1988/1990): 127-205.

- Mazower, Mark. Salonica, City of Ghosts: Christians, Muslims and Jews, 1430-1950. 2004. Ponatis, New York: Alfred A. Knopf, 2005.

- Mazzini, Federico. „Kriegserfahrungen: Italienische Soldaten an der italienisch-österreichischen Front." V: Krieg in den Alpen: Österreich-Ungarn und Italien im Ersten Weltkrieg 1914-1918, ur. Nicola Labanca in Oswald Überegger, 129-53. Wien, Köln, Weimar: Böhlau, 2015.

- Meyer, Jessica. Men of War: Masculinity and the First World War in Britain, Genders and Sexualities in History. New York: Palgrave Macmillan, 2009.

- Mintz, Sidney W. in Christine M. Du Bois, »The Anthropology of Food and Eating. « Annual Review of Anthropology 31 (2002): 99-119.

- Nachtigal, Reinhard. Russland und seine österreichisch-ungarischen Kriegsgefangenen (1914-1918). Remshalden: Greiner, 2003.

- Novak-Popov, Irena. »'Pozabljena' slovenska pričevanja iz vélike vojne." Jezik in slovstvo 50, št. 1 (2005): 9-24.

- Plahuta, Slavica, ur. Kuharska knjiga - Libro di ricette. Nova Gorica: Mestna občina Nova Gorica, 2006.

- Rachamimov, Alon [zdaj Iris]. "Normalität als Travestie: Das Theaterleben k.u.k. Kriegsgefangenenoffiziere in Rußland, 1914-1920."V: Glanz - Gewalt - Gehorsam. Militär und Gesellschaft in der Habsburgermonarchie (1800 bis 1918), ur. Laurence Cole, Martin Scheutz in Christa HämmerleEhrmann, 101-26. Essen: Klartext, 2010.

- Rachamimov, Alon [zdaj Iris]. POWs and the Great War: Captivity on the Eastern Front, The Legacy of the Great War Series. Oxford, New York: Bloomsbury Academic, 2002.

- Rachamimov, Alon [zdaj Iris]. »The Disruptive Comforts of Drag: (Trans)Gender Performances among Prisoners of War in Russia, 1914-1920." American Historical Review 111 (April 2006): 362-82.

- Rauchensteiner, Manfried. Der Tod des Doppeladlers: Osterreich-Ungarn und der Erste Weltkrieg. Graz, Wien, Köln: Böhlau, 1997.

- Roper, Michael. »Re-Remebering the Soldier Hero: The Psychic and Social Construction of Memory in Personal Narratives of the Great War." History Workshop Journal 50 (2000): 181-204.

- Sandgruber, Roman. Frauensachen - Männerdinge: Eine "sächliche" Geschichte der zwei Geschlechter. Wien: Ueberreuter, 2006.

- Schaumann, Walther. Die Bahnen zwischen Ortler und Isonzo 1914-1918. Wien: Bohmann, 1991.

- Schindler, John R. „Disaster on the Drina: The Austro-Hungarian Army in Serbia, 1914." War in History 9 (2002): 159-95.

- Schubert, Peter. Piava 1918: Zadnja bitka avstro-ogrske monarhije. Prev. Tone Perčič. Celovec, Ljubljana, Dunaj: Mohorjeva družba, 2001.

- Sluga, Miha. "Slovenski vojaki v prvi svetovni vojni: 1. del, Od sarajevskega atentata do vojne z Italijo." Časopis za zgodovino in narodopisje 80, št. 1 (2009): 31-62.

- Sluga, Miha. "Slovenski vojaki v prvi svetovni vojni: 2. del, Vrhunec vélike vojne.« Casopis za zgodovino in narodopisje 80, št. 2 (2009): 82-112.

- Sluga, Miha. "Slovenski vojaki v prvi svetovni vojni: 3. del, Poslednje leto vojne in monarhije." Časopis za zgodovino in narodopisje 80, št. 3 (2009): 79-109.

- Smith, Sidonie in Julia Watson. Reading Autobiography: A Guide for Interpreting Life Narratives, 2. izd. Minneapolis: University of Minnesota Press, 2010.

- Stone, Norman. „Die Mobilmachung der österreichisch-ungarischen Armee 1914." Militärgeschichtliche Mitteilungen 16 (1974): 67-95. 
- Svoljšak, Petra. „Pisanje kot zdravilo ali oznanilo bodočim rodovom: Po slovenskih spominskih poteh vélike vojne.« Acta Histriae 19, št. 3 (2011): 523-40.

- Svoljšak, Petra. "Prva svetovna vojna in Slovenci: Oris slovenskega zgodovinopisja, publicistike in spominske literature o prvi svetovni vojni.« Zgodovinski časopis 47 (1993): 263-87, 547-67.

- Svoljšak, Petra. "Prva svetovna vojna in Slovenci 1994-2014." Prispevki za novejšo zgodovino 55, št. 2 (2015).

- Svoljšak, Petra. »Slovenci v primežu avstrijske cenzure.« V: Velika vojna in Slovenci: 1914-1918, ur. Peter Vodopivec in Katja Kleindienst, 109-27. Ljubljana: Slovenska matica, 2005.

- Svoljšak, Petra. »Slovenski vojni ujetniki v prvi svetovni vojni.« V: Sledi prve svetovne vojne v mojem kraju, ur. Ljudmila Bezlaj Krevel, 24-33. Ljubljana: Zveza prijateljev mladine Slovenije, Komisija za delo zgodovinskih krožkov, 2014.

- Šteh, Bogdan. "Mamin paket zavit v 'veleizdajalsko vsebino': slovenski vojak in politika med prvo svetovno vojno."Zgodovina za vse 15, št. 1 (2008): 139-50.

- Štepec, Marko. »Izkušnja vojne v dnevnikih in spominih slovenskih vojakov.« V: Sledi prve svetovne vojne v mojem kraju, ur. Ljudmila Bezlaj Krevel, 14-23. Ljubljana: Zveza prijateljev mladine Slovenije, Komisija za delo zgodovinskih krožkov, 2014.

- Thompson, Mark. The White War: Life and Death on the Italian Front 1915-1919. 2008. Ponatis, London: Basic Books, 2009.

- Tucker, Todd. The Great Starvation Experiment: The Heroic Men Who Starved so That Millions Could Live. New York: Simon and Schuster, 2006.

- Ude, Lojze. "Upori slovenskega vojaštva v avstro-ogrski armadi." Zgodovinski časopis 22, št. 3-4 (1968): 185-205.

- van Creveld, Martin. Supplying War: Logistics from Wallenstein to Patton, 2. izd. Cambridge, New York: Cambridge University Press, 2004.

- Verginella, Marta. »La guerra è un'arte egoistica e crudele: Esperienze di guerra negli scritti di soldati austro-ungarici di nazionalità slovena." V: 1914-1918: Scampare la guerra: Renitenza, autolesionismo, comportamenti individuali e collettivi di fuga e la giustizia militare nella Grande Guerra, ur. Lucio Fabi, 99-107. Ronchi dei Legionari: Centro culturale pubblico polivalente, 1994.

- Verginella, Marta. "Soška fronta v slovenskem tisku in zapiskih slovenskih vojakov.«V: Soški protokol, ur. Andreas Moritsch in Gudmund Tributsch, 51-56. Celovec, Ljubljana, Dunaj: Mohorjeva založba, 1994.

- Verginella, Marta. „Velika vojna v avtobiografskih zapiskih slovenskih vojakov.« V: Velika vojna in Slovenci: 1914-1918, ur. Peter Vodopivec in Katja Kleindienst, 175-84. Ljubljana: Slovenska matica, 2005.

- Verginella, Marta. "Zgodovinopisna raba avtobiografskih virov in značilnosti ženskega avtobiografskega pisanja." V: Avtobiografski diskurz: teorija in praksa avtobiografije v literarni vedi, humanistiki in družboslovju, Studia litteraria, ur. Alenka Koron in Andrej Leben, 95-108. Ljubljana: Založba ZRC, 2011.

- Wagner, Walter. "Die k.(u.)k. Armee - Gliederung und Aufgabenstellung." V: Die Habsburgermonarchie 1848-1918, ur. Adam Wandruszka in Peter Urbanitsch, zv. 5, Die bewaffnete Macht, 142-633. Wien: Österreichische Akademie der Wissenschaften, 1987.

- Wilcox, Vanda. "Tra testo e corpo: l'esperienza fisica della Prima guerra mondiale negli scritti dei soldati.« Memoria e Ricerca: Rivista di Storia Contemporanea, št. 38 (2011): 25-40.

- Wurzer, Georg. Die Kriegsgefangenen der Mittelmächte in Russland im Ersten Weltkrieg. Göttingen: Isd, 2005.

- Zajc, Neža. »Aleksander Trušnovič.« V: Med domom in svetom, ur. Igor Grdina, 263-79. Ljubljana: Založba ZRC, 2011.

Viri:

- "Dnevnik škofa Jegliča," tipkopisni prepis. Zgodovinski inštitut Milka Kosa, ZRC SAZU.

- Gaberc-Gaberski, Vinko V. Brez slave: spomini na svetovno vojno. [Celje]: samozaložba, 1935.

- Hacin, Janko. Vsi ti mladi fantje. Ljubljana: Slovenska matica, 2002.

- Hameršak, Jože. Skoz prvo svetovno. Ur. Milan Dolgan. Ljubljana: Mladinska knjiga, 1994. 
- Hawlina, Otto. „Galicija 1914: Vojni zapiski od junija 1914 do januarja 1915.« Prev. Peter Hawlina, neobjavljen rokopis v privatni lasti.

- Holz, Eva. »Dnevnik Cirila Prestorja iz 1. svetovne vojne.« Kronika 34, št. 1/2 (1986): 72-88.

- Jagodič, Karel. »Med življenjem in smrtjo: Iz dnevnikov in pisem iz I. svetovne vojne.« Ur. Janko Moder. Borec: Revija za zgodovino NOB in ohranjanje revolucionarnih tradicij 40 (1988): 695-766.

- Južnič, Stanislav. »Soška fronta v zapisih Jožeta Selana iz Novih sel.»Kronika 46, št. 3 (1998): 93-96.

- Kreisler, Fritz. Four Weeks in the Trenches: The War Story of a Violinist. Boston, New York: Houghton Mifflin, 1915.

- Lampič, Rudolf. "Moja pot $\mathrm{v}$ svetovni vojni,« neobjavljen tipkopis. http://www.dlib. si/?URN=URN:NBN:SI:DOC-ASOGCWT2.

- Ličan, Aleksander. Spomini iz Sibirije. Ilirska Bistrica: Društvo za krajevno zgodovino in kulturo, 2006.

- Malgaj, Franjo. Vojni spomini 1914-1919. Ur. Marijan F. Kranjc in Janko Štampfl. Maribor: ProAndy, 2009.

- Matičič, Ivan. Na krvavih poljanah: Trpljenje in strahote z bojnih pohodov bivšega slovenskega planinskega polka. 1922. Ponatis, Ljubljana: Karantanija, 2006.

- Milčinski, Fran. Dnevnik 1914-1920. Ur. Goran Schmidt. Ljubljana: Slovenska matica, 2000.

- Prešeren, Jakob. Vojak 1915-1918. Celje: Celjska Mohorjeva družba, 2014.

- Reberšek, Franc. "Pisma slovenskega vojaka iz I. svetovne vojne. UU. Janez Cvirn. Borec: Revija za zgodovino NOB in ohranjanje revolucionarnih tradicij 40 (1988): 767-814.

- Rueh, Franc. Moj dnevnik: 1915-1918. Ur. Igor Vilfan. Ljubljana: Slovenska matica, 1999.

- Schubert, Franz Xaver. »Tagebuch: aus losen kurz nach dem Erlebnis verfassten Tagebuchblättern 1943 zusammengestellt und ergänzt, " neobjavljen tipkopis. Österreichisches Staatsarchiv, Kriegsarchiv, Nachlässe und Sammlungen, NL B /833, nr. 2.

- Trdina, Janez. Zbrano delo, zv. 1: Spomini. Ur. Janez Logar, Zbrana dela slovenskih pesnikov in pisateljev. Ljubljana: Državna založba Slovenije, 1946.

- Zlobec, Andrej. V viharju prve svetovne vojne. Ur. Dušica Kunaver, V vihri petih vojn, 1. Ljubljana: samozaložba, 2010.

- Zupančič, Franc. Dnevnik: 1914-1918. Ur. Jasmina Pogačnik. Ljubljana: Slovenska matica, 1998.

Rok Stergar

FOOD ON WORLD WAR I BATTLEFIELDS: EXPERIENCES OF SLOVENE SOLDIERS

S UMMARY

Even though the Austro-Hungarian military was fully aware of the many challenges of keeping soldiers appropriately provisioned and actively prepared to do so in the best possible manner, it became obvious as soon as the war began that the food supply was lacking or even non-existent. The relatively mobile fighting in the Balkans and on the Eastern Front exposed the many failings of the military logistics, often forcing soldiers to rely on their "iron rations" or even go hungry for a few days.

As the war progressed, the military supply and support managed to solve some of the most obvious logistical problems, however, it could not do a lot about the shortage of food. From 1916 onwards there simply was not enough food to distribute. Poor harvests and the Allied blockade caused a shortage of food that affected not only the civilian population but also the military. Additionally, the wear and tear on the transport network proved increasingly hard to mend and consequently when food was available it frequently could not reach the frontline units.

The military tried to alleviate these problems by introducing substitutes, by increasing efficiency even the parts of animals that were usually discarded were now put to use -, and by growing some of its own food. Nevertheless, rations were getting ever smaller and from the second half of 1917 most soldiers, NCOs, and even officers were constantly hungry or starving. Soldiers tried to compensate by buying food, by plundering, foraging, and hunting. They ate almost anything: not only stolen potatoes 
and turnips, but also sugar beets, wild herbs and vegetables, fruit, and even dogs or cats. Furthermore, food parcels from home grew in importance; even a slice of bread with some cured meat meant a world to a starving soldier. However, in spite of all the help they got from home and their own resourcefulness, hunger was an almost universal experience in 1918. In the autumn of 1918 the average AustroHungarian soldier on the Italian front weighed barely more than 50 kilograms.

During World War I, ensuring an adequate and timely supply of soldiers' rations was a serious problem for all the belligerents. Because of the Allied naval blockade, the Central Powers faced an even greater challenge. However, the inability of the Austro-Hungarian military to provide soldiers with sufficient rations was almost unparalleled. The German Army, for example, managed the situation much better and German soldiers were better supplied even when the civilian population suffered from severe shortages and starvation.

An analysis of diaries, memoires, and letters of Slovene soldiers provides an insight in the experiences of Austro-Hungarian frontline soldiers as well as identifies the different factors that affected them. Adequate provisioning depended on the availability of food and transport but also on the intensity of fighting and its mobility. Weather and terrain could further impede the efforts to keep up with the enormous demands of the army. Furthermore, the experiences of individual soldiers depended on their position in the armed forces, their resourcefulness, and - ultimately - their subjective perception of the situation. 